Ground Improvement

Volume 170 Issue GI1

Creep improvement factors for

vibro-replacement design

Sexton, Sivakumar and McCabe
Proceedings of the Institution of Civil Engineers

Ground Improvement 170 February 2017 Issue Gl1

Pages 35-56 http://dx.doi.org/10.1680/jgrim.16.00029

Paper 1600029

Received 13/09/2016 Accepted 06/01/2017

Keywords: columns/foundations/granular materials

\title{
Creep improvement factors for vibro-replacement design
}

1 Brian G. Sexton BE, PhD, MIEI

Geotechnical Engineer, AGL Consulting, Dublin, Ireland; formerly College of Engineering and Informatics, National University of Ireland, Galway, Ireland

2 Vinayagamoothy Sivakumar MSC, DIC, PhD, PGCHET Reader, School of Natural and Built Environment, Queens University of Belfast, Belfast, Northern Ireland
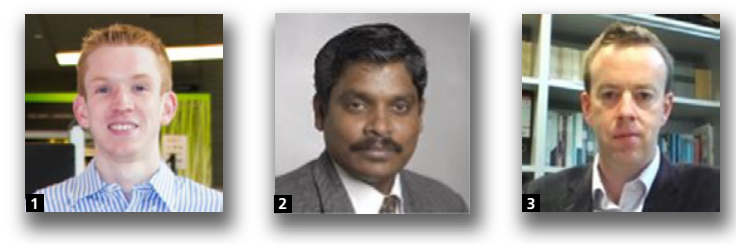

Although the vibro-replacement stone column technique is being deployed increasingly in soft cohesive soil deposits in which creep settlements may be significant/dominant, the majority of existing stone column settlement design methods are either non-specific or pertain to primary settlement only. Consequently, in the absence of further guidance, designers sometimes apply the same settlement improvement factor to creep settlements that they have estimated for primary settlements. In this paper, Plaxis 2D finite-element analyses carried out in conjunction with the elasto-viscoplastic soft soil creep model have indicated that settlement improvement factors are lower when creep is considered and therefore the design of stone columns ignoring creep is unconservative. These analyses were used to establish the impact of a range of relevant variables on 'primary', 'total' and 'creep' settlement improvement factors, leading to the development of a simplified empirical approach for predicting creep settlement improvement factors for use in conjunction with an existing primary settlement design method.

\section{Notation}

A

$A_{\mathrm{c}}$

$A_{\mathrm{c}} / A$

$C_{\mathrm{c}}$

$C_{\mathrm{s}}$

$C_{\alpha}$

$c^{\prime}$

$D_{\text {c }}$

$E^{\mathrm{ref}}$

$E_{\text {oed }}$

$E_{\text {ur }}$

$E_{50}$

$e$

$e_{\mathrm{p}}$

$e_{0}$

H

$K_{0}$

$K_{0}^{\mathrm{nc}}$

k cross-sectional area of soil unit treated with granular material

cross-sectional area of granular column

area-replacement ratio

compression index

swelling index

coefficient of secondary compression/creep coefficient

effective cohesion

column diameter

reference modulus

oedometric modulus

unload-reload modulus

secant/triaxial modulus

void ratio

end-of-primary (EOP) void ratio

initial void ratio

layer thickness

coefficient of lateral earth pressure at rest

coefficient of lateral earth pressure in the normally

consolidated condition

constant dependent on column arrangement

(square, triangular or hexagonal)

\begin{tabular}{|c|c|}
\hline$k, k_{x}, k_{y}$ & $\begin{array}{l}\text { permeability, horizontal permeability, vertical } \\
\text { permeability }\end{array}$ \\
\hline$m$ & $\begin{array}{l}\text { power dictating the stress dependency of soil } \\
\text { stiffness (hardening soil model) }\end{array}$ \\
\hline$n$ & settlement improvement factor, $n=\delta_{\text {untreated }} / \delta_{\text {treated }}$ \\
\hline$n_{\text {creep }}$ & ‘creep’ settlement improvement factor \\
\hline$n_{\text {primary }}$ & 'primary' settlement improvement factor \\
\hline$n_{\text {total }}$ & $\begin{array}{l}\text { ‘total' settlement improvement factor } \\
\text { (i.e. primary + creep) }\end{array}$ \\
\hline$n_{2}$ & Priebe's (1995) settlement improvement factor \\
\hline$p, p^{\prime}$ & $\begin{array}{l}\text { mean principal total stress, mean principal } \\
\text { effective stress }\end{array}$ \\
\hline$p^{\text {ref }}$ & reference pressure \\
\hline$p_{\mathrm{a}}$ & applied load/load level \\
\hline$p_{\mathrm{p}}$ & $\begin{array}{l}\text { preconsolidation stress/pressure (three } \\
\text { dimensional) }\end{array}$ \\
\hline$q$ & deviatoric stress \\
\hline$R_{\mathrm{c}}$ & column radius \\
\hline$s$ & column spacing \\
\hline$t$ & end time \\
\hline$t_{0}$ & time at which creep begins \\
\hline$\gamma$ & bulk unit weight \\
\hline$\Delta S_{\mathrm{c}}$ & vertical displacement of column \\
\hline$\Delta S_{\mathrm{s}}$ & vertical displacement of soil \\
\hline
\end{tabular}




$\begin{array}{ll}\Delta \sigma & \text { load level } \\ \delta & \text { settlement } \\ \kappa^{*} & \text { swelling index } \\ \lambda^{*} & \text { compression index } \\ \mu^{*} & \text { creep coefficient/index } \\ v & \text { Poisson ratio } \\ v_{\mathrm{ur}} & \text { Poisson ratio for unloading-reloading } \\ \sigma_{\mathrm{c}} & \text { stress in the column } \\ \sigma_{\mathrm{p}} & \text { preconsolidation stress/pressure (one dimensional) } \\ \sigma_{\mathrm{s}} & \text { stress in the soil } \\ \sigma_{y y}^{\prime} & \text { effective vertical stress } \\ \sigma_{0} & \text { initial effective stress/pressure (one dimensional) } \\ \phi^{\prime} & \text { friction angle } \\ \psi & \text { dilatancy angle }\end{array}$

\section{Introduction}

The majority of research conducted to date into the behaviour of vibro-replacement stone columns has focused on their effectiveness in improving bearing capacity or reducing primary settlement (e.g. Ambily and Gandhi, 2007; Barksdale and Bachus, 1983; Black et al., 2011; Mitchell and Huber, 1985; Watts et al., 2000). Stone columns accelerate consolidation, meaning that creep may contribute a significant proportion of post-construction settlement. Given that the magnitude of creep settlements may be very significant in some soft organics soils (e.g. Simons and Som, 1970), it is surprising that the ability of stone columns to arrest long-term creep settlements has received scant attention to date.

Settlement design methods typically involve the direct prediction of a settlement improvement factor, $n=\delta_{\text {untreated }} / \delta_{\text {treated }}$, defined as the ratio of the settlement of untreated ground (i.e. no columns) divided by the settlement of ground treated with stone columns. This settlement improvement factor can, in turn, be used to predict the settlement of treated ground. Other than an analytical formulation by Madhav et al. (2009, 2010) accounting for creep settlements, the majority of the analytical methods for determining $n$ values are either nonspecific or pertain to primary settlement only (e.g. Castro and Sagaseta, 2009; Priebe, 1995; Pulko et al., 2011), and in the absence of further guidance, designers sometimes apply these methods to estimate the improvement to both creep and primary settlements.

Sexton and McCabe (2012, 2013, 2015) carried out numerical studies using a soil model based on the isotache concept (the soft soil creep (SSC) model) in conjunction with the Plaxis 2D finite-element (FE) program (Brinkgreve et al., 2011) to gauge the influence of creep on stone column settlement performance in a soft single-layer soil profile. It was concluded that columns arrested long-term creep settlement but not to the same extent as primary settlement. Similar conclusions were obtained by Sexton and McCabe (2016) and Sexton et al. (2016) for a multi-layer soil profile; the soil model used in the latter study incorporated anisotropy, bonding and destructuration. Test data to support these numerical trends (at least in a qualitative sense) are available from

- laboratory testing in a modified triaxial cell carried out by Moorhead (2013)

- back-analyses of two serviceability failures by Pugh (2016), from which it was concluded that while the primary settlements of the treated ground were in keeping with those predicted by Priebe's (1995) analytical method (with a friction angle of $40^{\circ}$ assumed for the column material), the reduction in creep settlement offered by stone columns was actually quite limited.

In this paper, a parametric study is carried out using FE analysis to establish the soil parameters that have the largest influence on 'primary', 'creep' and 'total' (i.e. primary + creep) settlement improvement factors and the stress transfer process from soil to column due to creep. Based on the FE output, a simple empirical approach to account for creep in the design of end-bearing granular columns has been developed, which is amenable to routine use by practising engineers. The approach can be used in conjunction with an existing primary settlement design method that captures all the key features of primary settlement behaviour.

\section{Stone column settlement design methods}

\subsection{The "unit cell"}

Although a small number of settlement design methods have been developed using plane strain (e.g. Van Impe and De Beer, 1983) or homogenisation techniques (e.g. Lee and Pande, 1998; Schweiger and Pande, 1986), the majority have been developed based on the unit-cell concept (e.g. Balaam and Booker, 1981; Castro and Sagaseta, 2009; Pulko et al., 2011). The unit-cell approach is used to model an infinite grid of regularly-spaced columns subjected to a uniform load (e.g. Figure 1), and is valid for large loaded areas except along the periphery. The amount of stone replacement is quantified using a dimensionless area-replacement ratio, $A_{\mathrm{c}} / A$ (Equation 1), where $A_{\mathrm{c}}$ denotes the cross-sectional area of the granular column ( $=\pi D_{\mathrm{c}}^{2} / 4$, where $D_{\mathrm{c}}$ is the column diameter), and $A$ denotes the cross-sectional area of its attributed 'unit cell' (dependent on the centre-to-centre column spacing, $s$, and the column arrangement, quantified by $k$, see Figure 1).

1. $\frac{A_{\mathrm{c}}}{A}=\frac{1}{k}\left(\frac{D_{\mathrm{c}}}{s}\right)^{2}$

\subsection{Elastic against elastic-plastic methods}

Analytical settlement design methods tend to be based on either elastic or elastic-plastic theory. Elastic-plastic methods, which are typically based on the Mohr-Coulomb failure 


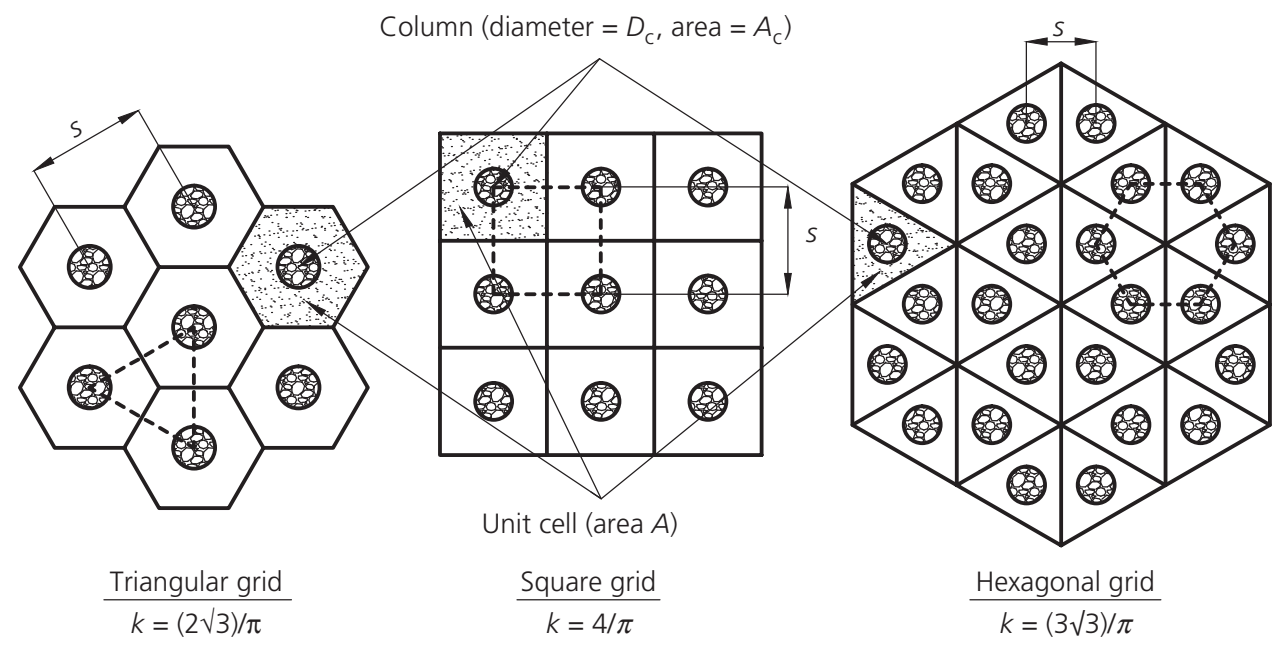

(a)

(b)

(c)

Figure 1. Typical column grids encountered in practice: (a) triangular, (b) square and (c) hexagonal

criterion, are preferable to purely elastic methods because the latter tend to over-predict settlement improvement factors, especially for soft soils. Elastic methods do not account for yielding of the column material, so they over-predict the stress concentration factor $\left(\mathrm{SCF}=\sigma_{\mathrm{c}} / \sigma_{\mathrm{s}}\right.$, where $\sigma_{\mathrm{c}}$ is the stress in the column and $\sigma_{\mathrm{s}}$ is the stress in the soil). For elastic methods that consider vertical deformation only, the SCF is equal to the ratio of the oedometric moduli of the column and soil materials $\left(E_{\mathrm{c}} / E_{\mathrm{s}}\right)$; elastic methods that consider both radial and vertical deformation yield slightly lower SCF values.

Sexton et al. (2014) used FE analyses to review numerous prediction approaches for primary settlement with a view to establishing their merits in capturing a range of features of stone column behaviour. Axisymmetric unit-cell analyses were conducted on end-bearing columns using the elasto-plastic hardening soil (HS) model. Predicted $n$ values and SCFs obtained using the methods of Castro and Sagaseta (2009) and Pulko et al. (2011) offered the best agreement with the FE analyses, capturing the effect of a wide range of input variables, including applied load $\left(p_{\mathrm{a}}\right)$, the friction $\left(\phi_{\mathrm{c}}^{\prime}\right)$ and dilatancy $\left(\psi_{\mathrm{c}}\right)$ angles of the column material and post-installation lateral earth pressure coefficient $(K)$.

\subsection{Review of Madhav et al. (2009, 2010)}

The method developed by Madhav et al. $(2009,2010)$ is based on an extension of an earlier method for primary settlement developed by Shahu et al. (2000), also based on the unit-cell assumption. However, in contrast to the methods reviewed in Sexton et al. (2014), the method developed by Shahu et al. (2000) incorporates a granular mat in order to combat/ reduce the high stress concentrations that occur near the top of the granular columns. Shahu et al. (2000) have used elastic theory to calculate the settlement of the granular column (e.g. Equation 2), where $\Delta S_{\mathrm{c}}$ and $\Delta h$ denote the settlements and thicknesses of each element of the column, respectively.

2. $\Delta S_{\mathrm{c}}=\frac{\sigma_{\mathrm{c}}}{E_{\mathrm{c}}} \Delta h$

Conventional $e-\log \sigma$ theory is used to calculate the settlement of each sub-layer of the soil $\left(\Delta S_{\mathrm{s}}\right)$ (e.g. Equation 3), where $\sigma_{0}$ is the initial overburden stress at the centre of each element and $e_{0}$ is its initial void ratio. The soil is assumed to be normally consolidated. In each element, the vertical displacement of the column is equal to the vertical displacement of the soil $\left(\Delta S_{\mathrm{c}}=\Delta S_{\mathrm{s}}\right)$, leading to Equation 4. The method does not consider radial displacement. An iterative procedure can then be used to solve for $\sigma_{\mathrm{c}}$ and $\sigma_{\mathrm{s}}$ in each element by combining Equations 4 and 5 (Equation 5 describes the equilibrium of vertical stresses in each element).

3. $\Delta S_{\mathrm{s}}=\frac{C_{\mathrm{c}}}{1+e_{0}} \Delta h \log \left(1+\frac{\sigma_{\mathrm{s}}}{\sigma_{0}}\right)$

4. $\sigma_{\mathrm{c}}=\frac{C_{\mathrm{c}}}{1+e_{0}} E_{\mathrm{c}} \log \left(1+\frac{\sigma_{\mathrm{s}}}{\sigma_{0}}\right)$

5. $p_{\mathrm{a}}=\sigma_{\mathrm{c}}\left(A_{\mathrm{c}} / A\right)+\sigma_{\mathrm{s}}\left(1-A_{\mathrm{c}} / A\right)$

Madhav et al. $(2009,2010)$ account for creep based on the principle that the stress on the soil will decrease as it creeps $\left(\Delta \sigma_{\mathrm{s}}\right)$ while the column (which does not creep) will assume the surplus 
load $\left(\Delta \sigma_{\mathrm{c}}\right)$, as illustrated in Equation 6. A similar load transfer mechanism has also been suggested by Mitchell and Kelly (2013). As a result of the stress unloading, the soil becomes overconsolidated. This overconsolidation effect is additional to Bjerrum's (1967) overconsolidation effect due to ageing.

6. $p_{\mathrm{a}}=\left(\sigma_{\mathrm{c}}+\Delta \sigma_{\mathrm{c}}\right)\left(A_{\mathrm{c}} / A\right)+\left(\sigma_{\mathrm{s}}-\Delta \sigma_{\mathrm{s}}\right)\left(1-A_{\mathrm{c}} / A\right)$

The settlements of the $i$ th layer of the granular column and soil are given by Equations 7 and 8, respectively, where the net settlement during creep is calculated as the creep settlement minus the rebound due to unloading ( $e_{\mathrm{p}}$ denotes the end-ofprimary (EOP) void ratio, $t_{0}$ denotes the time at which creep begins and $t$ denotes the end time). Using the compatibility condition $\left(\Delta S_{\mathrm{c}}=\Delta S_{\mathrm{s}}\right)$, the additional stress carried by the column during creep is calculated using Equation 9. An iterative procedure can then be used to calculate $\Delta \sigma_{\mathrm{c}}$ and $\Delta \sigma_{\mathrm{s}}$ in each element by combining Equations 6 and 9 .

7. $\Delta S_{\mathrm{c}}=\frac{\sigma_{\mathrm{c}}+\Delta \sigma_{\mathrm{c}}}{E_{\mathrm{c}}} \Delta h$

8.

$$
\begin{aligned}
\Delta S_{\mathrm{s}}= & \frac{C_{\mathrm{c}}}{1+e_{0}} \Delta h \log \left(1+\frac{\sigma_{\mathrm{s}}}{\sigma_{0}}\right)+\frac{C_{\alpha}}{1+e_{\mathrm{p}}} \Delta h \log \left(\frac{t}{t_{0}}\right) \\
& -\frac{C_{\mathrm{s}}}{1+e_{\mathrm{p}}} \Delta h \log \left(\frac{\sigma_{\mathrm{s}}}{\sigma_{\mathrm{s}}-\Delta \sigma_{\mathrm{s}}}\right)
\end{aligned}
$$

9.

$$
\begin{aligned}
\Delta \sigma_{\mathrm{c}}= & \frac{C_{\mathrm{c}}}{1+e_{0}} \log \left(1+\frac{\sigma_{\mathrm{s}}}{\sigma_{0}}\right)+\frac{C_{\alpha}}{1+e_{\mathrm{p}}} \log \left(\frac{t}{t_{0}}\right) \\
& \left.-\frac{C_{\mathrm{s}}}{1+e_{\mathrm{p}}} \log \left(\frac{\sigma_{\mathrm{s}}}{\sigma_{\mathrm{s}}-\Delta \sigma_{\mathrm{s}}}\right)\right] \times E_{\mathrm{c}}-\sigma_{\mathrm{c}}
\end{aligned}
$$

As the Madhav et al. $(2009,2010)$ method is based on elastic theory, $n$ values will be over-predicted unless adequate thickness of granular mat is provided. Additionally, the method is based on the assumption that primary consolidation is finished before creep begins (creep 'hypothesis A'), which has been denounced in recent years; creep 'hypothesis B' (also known as the isotache concept, e.g. Degago et al., 2011), which models creep occurring concurrently with primary consolidation, is preferred. The Madhav et al. (2009, 2010) method also assumes that the soil is initially normally consolidated so that only $C_{\mathrm{c}}$ influences primary settlement, as shown in Equation $3\left(C_{\mathrm{s}}\right.$ is only taken into account when considering the unloading from soil to column due to creep, e.g. Equation 8). Finally, the method necessitates an iterative solution technique, whereas a closed-form solution, the goal of the study reported in this paper, would be preferable from a designer's standpoint.

\section{Numerical modelling preliminaries}

\subsection{Soil models}

The FE analyses in this paper have been carried out in conjunction with the Plaxis 2D FE program. The elastoviscoplastic SSC model (Vermeer and Neher, 1999; Vermeer et al., 1998), based on the isotache concept, is used to model the host clay, and the elasto-plastic HS model (Schanz et al., 1999 ) is used to model the granular column material.

\subsection{Range of soft clay soil parameters}

Soil parameters from a selection of well-researched soft clay sites have been compiled to help identify suitable parameter ranges for the study. Strength and compressibility parameters have been summarised in Table 1; the compressibility parameters have been used to develop the plot of creep ratio, $\left(\lambda^{*}-\kappa^{*}\right) / \mu^{*}$, against $\mu^{*}$ in Figure $2\left(\lambda^{*}, \kappa^{*}\right.$ and $\mu^{*}$ are the isotropic equivalents of the one-dimensional (1D) compression, $C_{\mathrm{c}}$, swelling, $C_{\mathrm{s}}$ and creep indices, $C_{\alpha}$, respectively). The properties of Bothkennar clay in Scotland may be considered as an approximate 'mid-range' of the selection in Figure 2, so its properties (Table 2) are adopted as the 'base case' for the parametric study.

The Bothkennar clay parameters in Table 2 are based on those used by Killeen and McCabe (2014), which are in turn based on ICE (1992). However, as creep was not considered by Killeen and McCabe (2014), the incremental load testing programme carried out by Nash et al. (1992) was used to derive additional parameters necessary for the SSC model. The soil parameters have been comprehensively validated in Sexton (2014) both by using the Plaxis 'soil test' facility to simulate the triaxial soil test data published in ICE (1992) and by simulating two field tests (described by Jardine et al. (1995)) on an unreinforced rigid pad footing at the Bothkennar site.

\subsection{The numerical model}

A standardised stratigraphy as shown in Figure 3 was preferred for the parametric study, enabling the effect of changing a single parameter to be examined. This profile (crust + clay) was preferred to a single-layer profile because clay sites reported in the literature generally include a stiff crust (formed by weathering and groundwater level fluctuations). The crust parameters in Table 2 are based on those used by Killeen and McCabe (2014), who identified the important influence of the crust on the mechanism of stone column behaviour; a stiff crust tends to confine columns in the upper layers, forcing bulging to occur in the deeper layers, which in turn enhances the loadcarrying capacity of columns.

Axisymmetry has been used to model the problem for the purposes of this numerical study (Figure 3). The vertical boundaries of the 'unit cell' are restrained laterally and the base is fixed in both the vertical and lateral directions. The left-hand side boundary of the unit cell shown in Figure 3 is a symmetry 
Table 1. Soil strength and compressibility parameters for soft clays

\begin{tabular}{|c|c|c|c|c|c|c|c|}
\hline Soil type & $\phi_{\mathrm{s}}^{\prime}: \operatorname{deg}$ & $S_{\mathrm{t}}$ & $\lambda^{*}$ & $\boldsymbol{\kappa}^{*}$ & $\mu^{*}$ & $\left(\lambda^{*}-\kappa^{*}\right) / \mu^{*}$ & References \\
\hline Bothkennar clay & $34 \cdot 0$ & $5-13$ & $0 \cdot 162$ & 0.023 & 0.0065 & $21 \cdot 43$ & $\begin{array}{l}\text { Hight et al. (1992); Killeen } \\
\text { and McCabe (2014) }\end{array}$ \\
\hline \multicolumn{8}{|l|}{ Swedish clays } \\
\hline Väsby clay & $30 \cdot 0$ & - & 0.326 & 0.038 & 0.0195 & $14 \cdot 74$ & Degago (2011) \\
\hline Skå-Edeby clay & $30 \cdot 0$ & $7-20$ & $0 \cdot 364$ & 0.050 & 0.0185 & $16 \cdot 96$ & $\begin{array}{l}\text { Degago (2011); Lo and } \\
\text { Hinchberger (2006) }\end{array}$ \\
\hline Bäckebol clay & - & 25 & 0.410 & $0 \cdot 010$ & 0.0205 & $19 \cdot 51$ & Yin and Graham (1989) \\
\hline \multicolumn{8}{|l|}{ Finnish clays } \\
\hline Haney clay & $32 \cdot 0$ & $6-10$ & $0 \cdot 105$ & $0 \cdot 016$ & $0.0020-0.0040$ & $22 \cdot 25-44 \cdot 50$ & $\begin{array}{l}\text { Vermeer and Neher (1999); } \\
\text { Yin and Karstunen (2011) }\end{array}$ \\
\hline Hut clay & $30 \cdot 0$ & 10 & 0.089 & 0.015 & 0.0018 & $40 \cdot 11$ & Suhonen (2010) \\
\hline Otanemi clay & $27 \cdot 7$ & $7-14$ & $0 \cdot 150$ & 0.015 & 0.0035 & 38.57 & Neher et al. (2003) \\
\hline \multicolumn{8}{|l|}{ Norwegian clays } \\
\hline Drammen clay & - & $\begin{array}{c}10- \\
12\end{array}$ & $0 \cdot 158$ & 0.004 & 0.0070 & $22 \cdot 00$ & Yin and Graham (1994, 1996) \\
\hline Ellingsrud clay & - & - & 0.237 & 0.008 & 0.0103 & $22 \cdot 26$ & Degago (2011) \\
\hline \multicolumn{8}{|l|}{ Other clays } \\
\hline Boston Blue clay (BBC) & $30 \cdot 0$ & 7 & $0.052-0.196$ & $0.013-0.049$ & $0.0015-0.0056$ & $26 \cdot 25$ & $\begin{array}{l}\text { Azzouz et al. (1990), } \\
\text { Fatahi et al. (2012) }\end{array}$ \\
\hline $\begin{array}{l}\text { Estuarine alluvium } \\
\text { (Avonmouth, UK) }\end{array}$ & - & - & $0 \cdot 110$ & 0.013 & 0.0116 & 8.37 & Nash and Ryde (2001) \\
\hline Batiscan clay, Canada & $25 \cdot 0$ & $2 \cdot 5$ & $0 \cdot 140$ & 0.013 & 0.0055 & 23.03 & Yin and Karstunen (2011) \\
\hline Saint-Herblain clay, France & $31 \cdot 0$ & $1 \cdot 0$ & $0 \cdot 126$ & 0.007 & 0.0074 & $16 \cdot 12$ & Yin and Karstunen (2011) \\
\hline $\begin{array}{l}\text { Hong Kong marine } \\
\text { deposits (HKMD) }\end{array}$ & $31 \cdot 0$ & $1 \cdot 6$ & 0.079 & 0.018 & 0.0027 & 23.03 & Yin and Karstunen (2011) \\
\hline Tagus Basin soils, Portugal & - & - & $0 \cdot 121$ & 0.029 & 0.0177 & $5 \cdot 20$ & Lopes (2011) \\
\hline
\end{tabular}

$S_{\mathrm{t}}$, sensitivity; $\phi_{\mathrm{s}}^{\prime}$, soil critical state friction angle

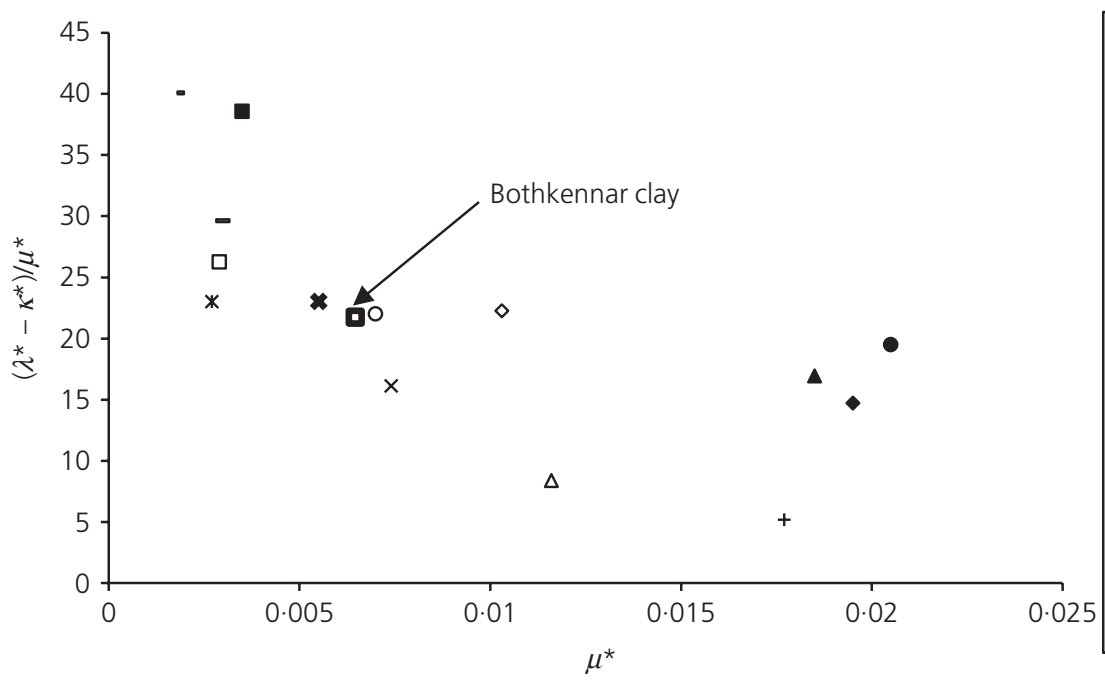

Bothkennar (Scotland)

- Väsby (Sweden)

- Skå-Edeby (Sweden)

- Bäckebol (Sweden)

- Haney (Finland)

- Hut (Finland)

- Otanemi (Finland)

- Drammen (Norway)

$\diamond$ Ellingsrud (Norway)

- Boston Blue clay (USA)

$\triangle$ Avonmouth alluvium (UK)

* Batiscan (Canada)

$\times$ Saint-Herblain (France)

* HKMD (China)

+ Tagus Basin (Portugal)

Figure 2. $\left(\lambda^{\star}-\kappa^{\star}\right) / \mu^{\star}$ against $\mu^{\star}$ for worldwide clays

boundary. In this study, a column diameter of $600 \mathrm{~mm}$ has been adopted (column radius, $R_{\mathrm{c}}=300 \mathrm{~mm}$ ), typical of that constructed in soft cohesive soil deposits using a $430 \mathrm{~mm}$ diameter poker.

The parameters used for the granular column material, documented in Table 3, have also been based on the work of Killeen and McCabe (2014). The HS model accounts for the stress dependency of soil stiffness using a power law (Equation 10; Brinkgreve et al., 2011), where $m$ denotes the power, and $E^{\text {ref }}$ denotes the reference stiffness modulus corresponding to a reference pressure, $p^{\text {ref }}$. According to Brinkgreve et al. (2011), $m=1 \cdot 0$ should be used for soft soils to simulate logarithmic compression behaviour, whereas $m=0.5$ is more suitable 
Table 2. Material parameters for the crust and clay layers

\begin{tabular}{|c|c|c|}
\hline & Crust & Clay \\
\hline Depth: m & $0 \cdot 0-1 \cdot 0$ & $1 \cdot 0-10 \cdot 0$ \\
\hline$\gamma: \mathrm{kN} / \mathrm{m}^{3}$ & 18.0 & $16 \cdot 5$ \\
\hline OCR & - & 1.5 \\
\hline POP & $15 \cdot 0$ & - \\
\hline$K_{0}$ & 1.0 & 0.54 \\
\hline$\phi_{s}^{\prime}: \operatorname{deg}$ & 34 & 34 \\
\hline$c^{\prime}: k P a$ & $3 \cdot 0$ & 1.0 \\
\hline$\psi_{s}: \operatorname{deg}$ & 0 & 0 \\
\hline$e_{0}$ & 1.0 & $2 \cdot 0$ \\
\hline$\lambda^{*}$ & 0.015 & $0 \cdot 162$ \\
\hline$\kappa^{\star}$ & 0.002 & 0.023 \\
\hline$\mu^{*}$ & 0.0006 & 0.0065 \\
\hline$v_{\text {ur }}$ & $0 \cdot 2$ & $0 \cdot 2$ \\
\hline$k_{x}: \mathrm{m} / \mathrm{d}$ & $1 \times 10^{-4}$ & $1 \times 10^{-4}$ \\
\hline$k_{y}: \mathrm{m} / \mathrm{d}$ & $6.9 \times 10^{-5}$ & $6.9 \times 10^{-5}$ \\
\hline
\end{tabular}

$\gamma$ is the bulk unit weight; POP is the pre-overburden pressure $=\sigma_{\mathrm{p}}-\sigma_{0}$, where $\sigma_{\mathrm{p}}$ is the $1 \mathrm{D}$ preconsolidation stress and $\sigma_{0}$ is the initial effective stress; OCR is the overconsolidation ratio $=\sigma_{\mathrm{p}} / \sigma_{0} ; K_{0}$ is the at-rest coefficient of lateral earth pressure; $c^{\prime}$ is the effective cohesion; $\psi_{\mathrm{s}}$ is the soil dilatancy angle; $v_{\mathrm{ur}}$ is the Poisson ratio for unloading-reloading; $k_{x}$ is the horizontal permeability; $k_{y}$ is the vertical permeability

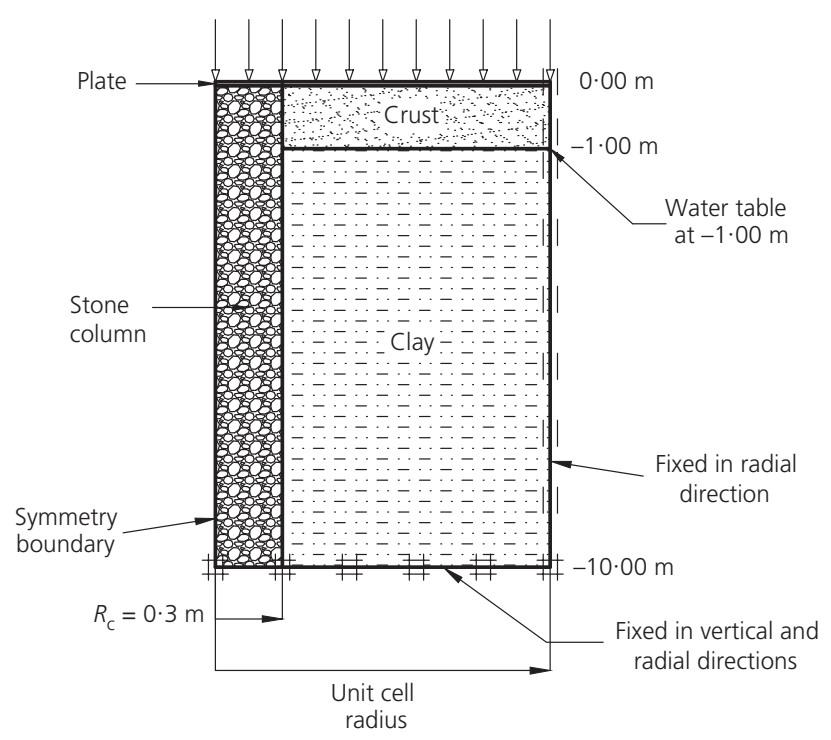

Figure 3. Soil profile (crust + clay)/axisymmetric unit cell

for sands and silts. The value of $m=0.3$ for the granular column material quoted in Table 3 is based on Gäb et al. (2008), as are the values of $E_{50}^{\text {ref }}$ (triaxial/secant modulus at $50 \%$ of the maximum stress), $E_{\text {oed }}^{\text {ref }}$ (oedometric modulus) and $E_{\text {ur }}^{\text {ref }}$ unload-reload modulus). For the HS model, $E_{50}^{\text {ref }}$ and $E_{\text {oed }}^{\text {ref }}$ control the positions of the shear hardening and volumetric hardening yield surfaces, respectively.

10. $E=E^{\text {ref }}\left(\frac{p}{p^{\text {ref }}}\right)^{m}$

\section{Numerical modelling}

\subsection{Analysis stages}

For the analyses carried out herein, the key stages are as follows

- The $K_{0}$ procedure (Brinkgreve et al., 2011) is used to generate the initial stresses; this method of initial stress generation can be used when all layers in the numerical model, including the water table, are horizontal. For the 'base case' described in Section 4.3, $K_{0}$ for the clay has been calculated according to Equation 11 (Brinkgreve et al., 2011), where $K_{0}^{\mathrm{nc}}$ denotes the coefficient of lateral earth pressure in the normally consolidated condition $\left(K_{0}^{\mathrm{nc}}=1-\sin \phi_{\mathrm{s}}^{\prime}\right)$ and $v_{\text {ur }}$ is the unload-reload Poisson ratio. A higher value of $K_{0}=1.0$ has been used for the crust.

$$
\text { 11. } K_{0}=K_{0}^{\mathrm{nc}} \mathrm{OCR}-\frac{v_{\mathrm{ur}}}{1-v_{\mathrm{ur}}}(\mathrm{OCR}-1)
$$

- End-bearing columns are 'wished-in-place' (e.g. Killeen and McCabe, 2014), after which a plastic nil-step is used to ensure any out-of-equilibrium stresses generated as a result of the installation method are restored.

- A plate element is placed at the surface of the unit cell over the soil and column; the plate acts as a loading platform and ensures the soil and column surfaces undergo equal settlement.

- A $100 \mathrm{kPa}$ load is applied in undrained conditions, after which a consolidation period is allowed. Once the excess pore pressures have dissipated, no further settlement occurs for the case with the 'almost zero' creep coefficient.

\subsection{Establishing the influence of creep on $n$}

The SSC model is based on the aforementioned isotache concept (strain rate approach/hypothesis B). The concept was first proposed by Šuklje (1957), and is based on a unique relationship between the creep rate, the current stress state and the current strain or void ratio $\left(\varepsilon^{\prime}-\sigma^{\prime}-\varepsilon\right)$, irrespective of the previous loading history (Bodas Freitas, 2008). Therefore, Casagrande's (1936) method cannot be used for separating the primary and creep settlement components (and for deriving separate $n$ values) under a given load increment. To overcome this, two sets of analyses are performed using the SSC model to establish the influence of creep.

- For the first set of analyses, a standard creep coefficient is used for the soil. For these analyses, 'total' settlement improvement factors (i.e. primary and creep together) can be calculated according to the following equation

12. $n_{\text {total }}=\frac{\delta_{\text {total }(\text { untreated })}}{\delta_{\text {total }(\text { treated })}}$ 
Table 3. Material parameters for the granular column material

\begin{tabular}{|c|c|c|c|c|c|c|c|c|c|c|}
\hline$\gamma: \mathrm{kN} / \mathrm{m}^{3}$ & $\phi_{c}^{\prime}: \operatorname{deg}$ & $\psi_{\mathrm{c}}: \operatorname{deg}$ & $c^{\prime}: \mathrm{kPa}$ & $E_{\text {oed }}^{\text {ref }}$ MPa & $E_{50}^{\text {ref }}: M P a$ & $E_{\mathrm{ur}}^{\text {ref: }} \mathrm{MPa}$ & $p_{\text {ref: }}: \mathrm{kPa}$ & $m$ & $k_{x}: m / d$ & $k_{y}: \mathrm{m} / \mathrm{d}$ \\
\hline $19 \cdot 0$ & 45 & 15 & 1 & 70 & 70 & 210 & 100 & 0.3 & $1 \cdot 7$ & 1.7 \\
\hline
\end{tabular}

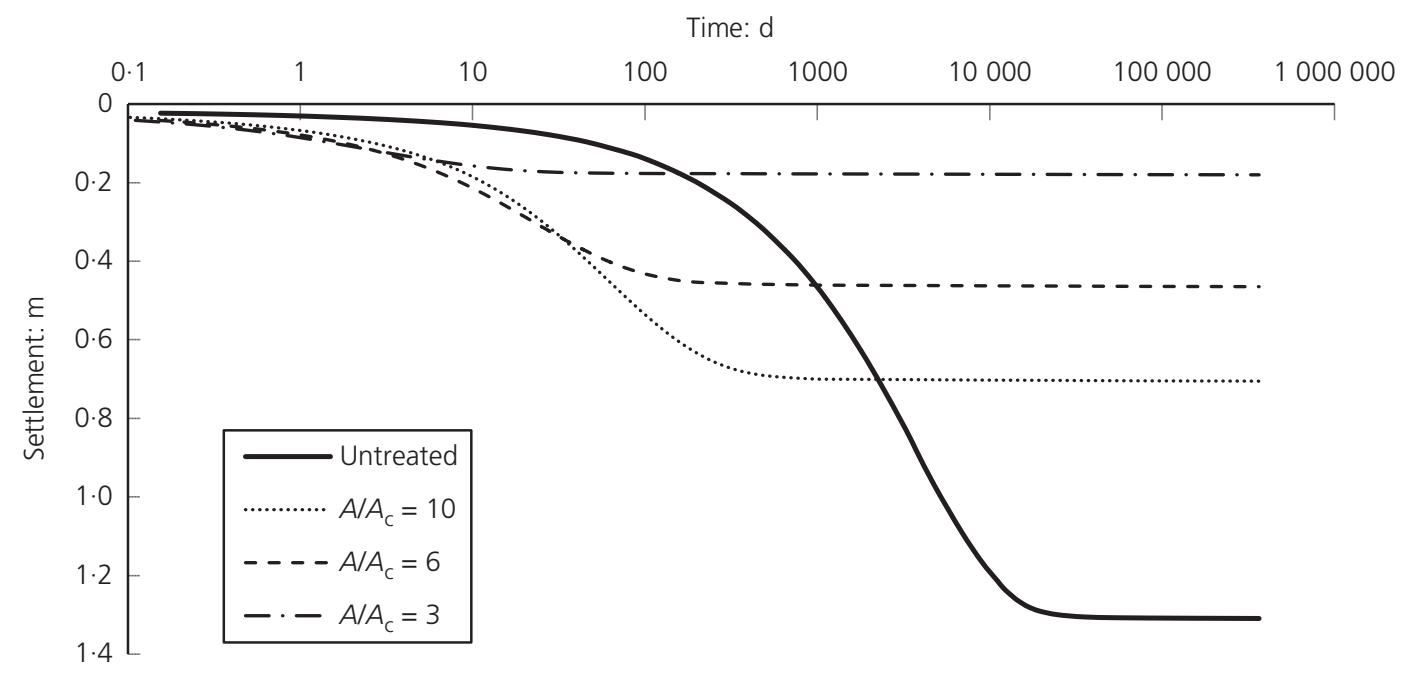

(a)

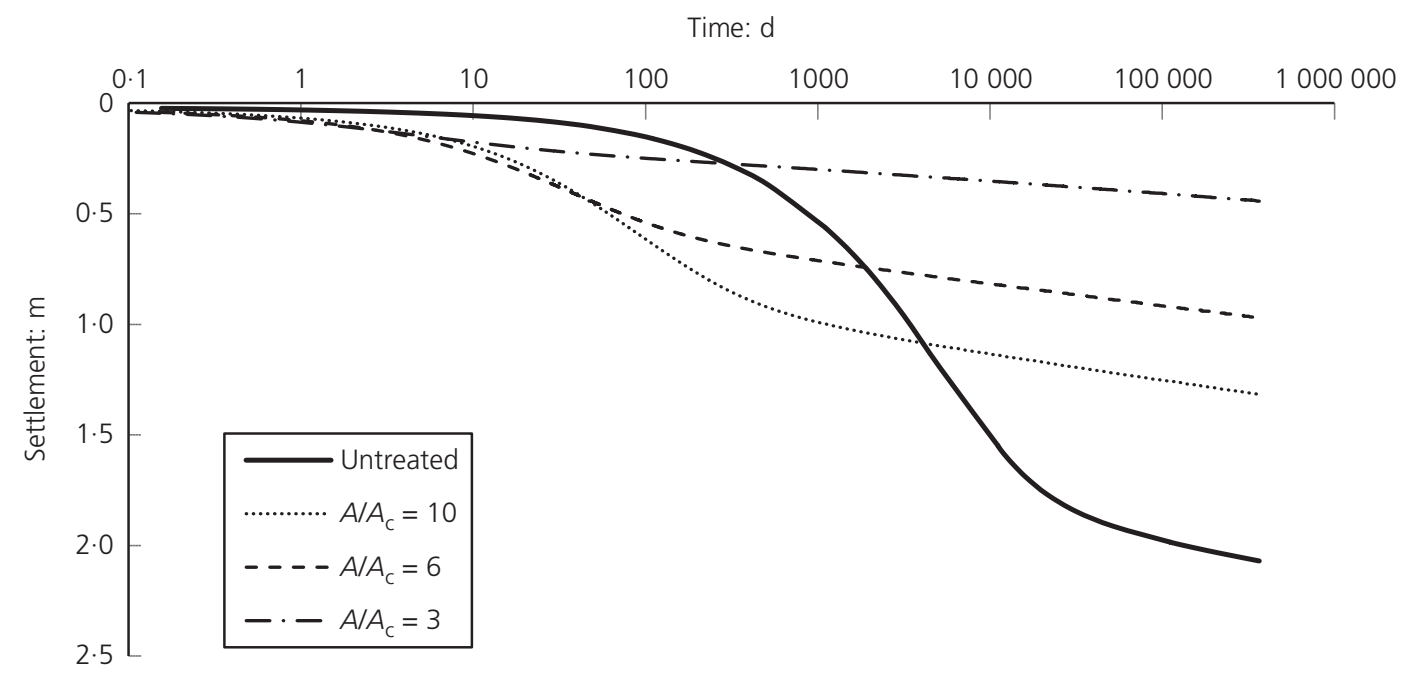

(b)

Figure 4. Settlement against log(time): (a) very low creep coefficient and (b) standard creep coefficient

'Creep' settlement improvement factors $\left(n_{\text {creep }}\right)$ can also be derived from these analyses based on the slopes of the settlement- $\log ($ time) plots after the complete dissipation of excess pore pressure (i.e. after EOP consolidation) according to Equation 13, where $\mu_{\text {untreated }}^{*}$ and $\mu_{\text {treated }}^{*}$ denote the slopes of the untreated and treated settlement-log(time) plots, respectively.

13. $n_{\text {creep }}=\frac{\mu_{\mathrm{untreated}}^{*}}{\mu_{\text {treated }}^{*}}$
For the second set, a very low creep coefficient is used for the soil ( $\approx 1 \%$ of the standard value), effectively removing the creep contribution; 'primary' settlement improvement factors can be calculated according to Equation 14. Numerical difficulties arise in Plaxis if $\mu^{*}=0$ is used.

14. $n_{\text {primary }}=\frac{\delta_{\text {primary }(\text { untreated })}}{\delta_{\text {primary }(\text { treated })}}$

For the second set, a very low creep coefficient is used for the soil ( $\approx 1 \%$ of the standard value), effectively removing 
the creep contribution; 'primary' settlement improvement factors can be calculated according to Equation 13 . Numerical difficulties arise in Plaxis if $\mu^{*}=0$ is used.

\section{3 'Base case' parameters}

For both sets of analyses, the parameters for the 'base case' are based on those of Bothkennar clay documented in Table 2. The water table is located at a depth of $1.0 \mathrm{~m}$. For the case with a standard creep coefficient, the relative percentages of primary/creep settlement to the total settlement of untreated ground under $p_{\mathrm{a}}=100 \mathrm{kPa}$ after $1,10,30,100$ and 1000 years are $79 / 21,74 / 26,71 / 29,68 / 32$ and $64 / 36$, respectively, although a wider range has been captured by the parametric study. The analyses have been carried out for $3<A / A_{\mathrm{c}}<10$, typical of the range encountered in practice as illustrated by the database of McCabe et al. (2009), where $A / A_{\mathrm{c}}$ is the reciprocal of the areareplacement ratio defined in Equation 1.

\section{Parametric study results}

\section{1 'Base case' time-settlement behaviour}

Settlement- $\log ($ time) plots for the 'base case' for both the untreated and treated cases are plotted in Figures 4(a) and 4(b) for the 'no creep' and standard cases, respectively. For the 'no creep' untreated case, primary consolidation settlement ceases after $\sim 20000 \mathrm{~d}$ ( $\sim 55$ years). For the untreated case with creep, primary consolidation takes $\sim 60000 \mathrm{~d}$ ( $\sim 165$ years). Nash (2001) has attributed these long consolidation durations to the low permeability and high compressibility characteristics of Bothkennar clay. With the inclusion of highly permeable granular columns at $A / A_{\mathrm{c}}=10$, an almost 50 -fold consolidation time reduction is experienced; at closer spacings, the consolidation times are shorter again. The consolidation time reduction factors are consistent with those reported by Kok Shien (2013) modelling stone columns using a similar axisymmetric unit-cell process.

\section{2 'Base case' settlement improvement factors}

The evolution of $n$ with time with and without creep is plotted in Figure 5 at $A / A_{\mathrm{c}}=10,6$ and 3. Initially, $n$ values for both cases are $<1 \cdot 0$, reflecting the fact that the settlement of treated ground occurs faster than that of untreated ground, and as such, are of no practical relevance. After EOP, the $n_{\text {total }}$ values are less than their $n_{\text {primary }}$ counterparts, consistent with the findings of the aforementioned numerical studies; the incorporation of creep leads to lower $n$ values than if primary consolidation was considered alone and therefore creep should be considered in vibro-replacement design.

The $n_{\text {primary, }} n_{\text {total }}$ (both after EOP) and $n_{\text {creep }}$ values for the base case are plotted in Figure 6(a). 'Total' settlement improvement factors are effectively a weighted average of 'primary' and 'creep' settlement improvement factors; the percentage differences between $n_{\text {primary }}$ and $n_{\text {creep }}$ (relative to $n_{\text {primary }}$ ) are larger at closer spacings $\left(63 \%\right.$ difference at $A / A_{\mathrm{c}}=3$ against $30 \%$

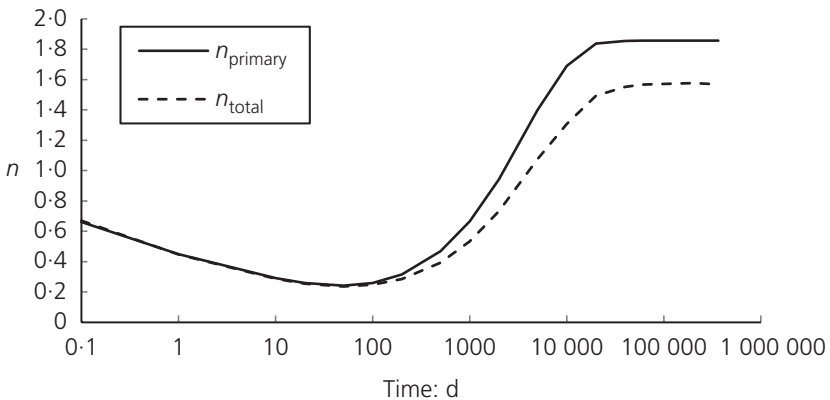

(a)

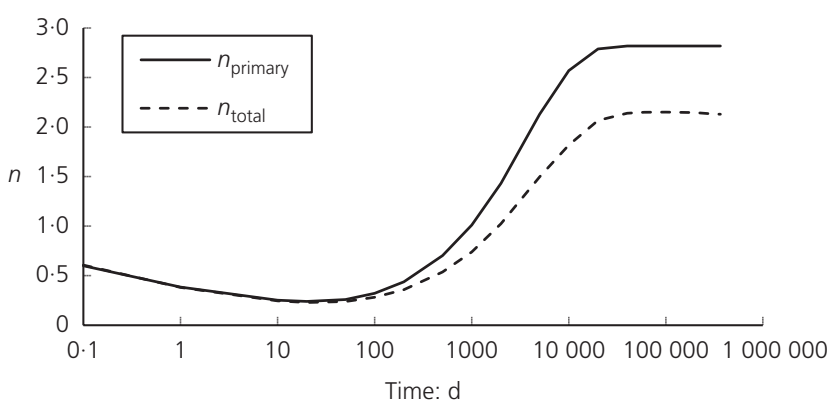

(b)

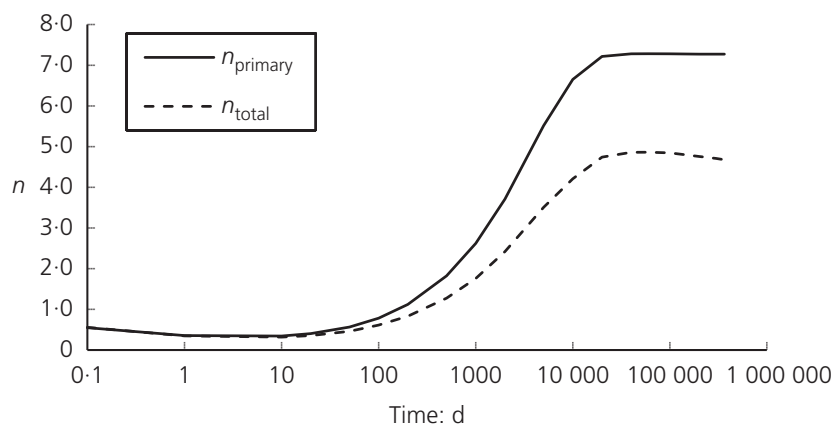

(c)

Figure 5. Evolution of $n$ with time: (a) $A / A_{c}=10$, (b) $A / A_{c}=6$ and (c) $A / A_{c}=3$

difference at $A / A_{\mathrm{c}}=10$ ). Superimposed on Figure 6(b) are $n_{\text {total }}$ and $n_{\text {primary }}$ values obtained using Madhav et al. $(2009,2010)$ and Shahu et al. (2000), respectively. For the problem considered (no granular mat, very soft soil profile), both methods significantly over-predict the $n$ values (as would be expected given that the methods are based on elastic theory, see Sections 2.2 and 2.3), although the $n_{\text {primary }}$ values exceed the $n_{\text {total }}$ values, consistent with the FE output here.

\section{3 'Base case' soil and column stresses}

The average vertical effective stresses $\left(\sigma_{y y}^{\prime}\right)$ in the soil and stone column after 100 years (without and with creep) for $A / A_{\mathrm{c}}=3$, 6 and 10 are plotted in Figures 7(a) and 7(b). The average stress in the soil (Figure 7(a)) for the 'with creep' case is lower than that for the 'without creep' case; the stress unloaded due to creep is transferred to the column (Figure 7(b)). Accordingly, SCFs are higher for the 'with creep' case (Figure 8(a)). The stress transfer process from soil to column 


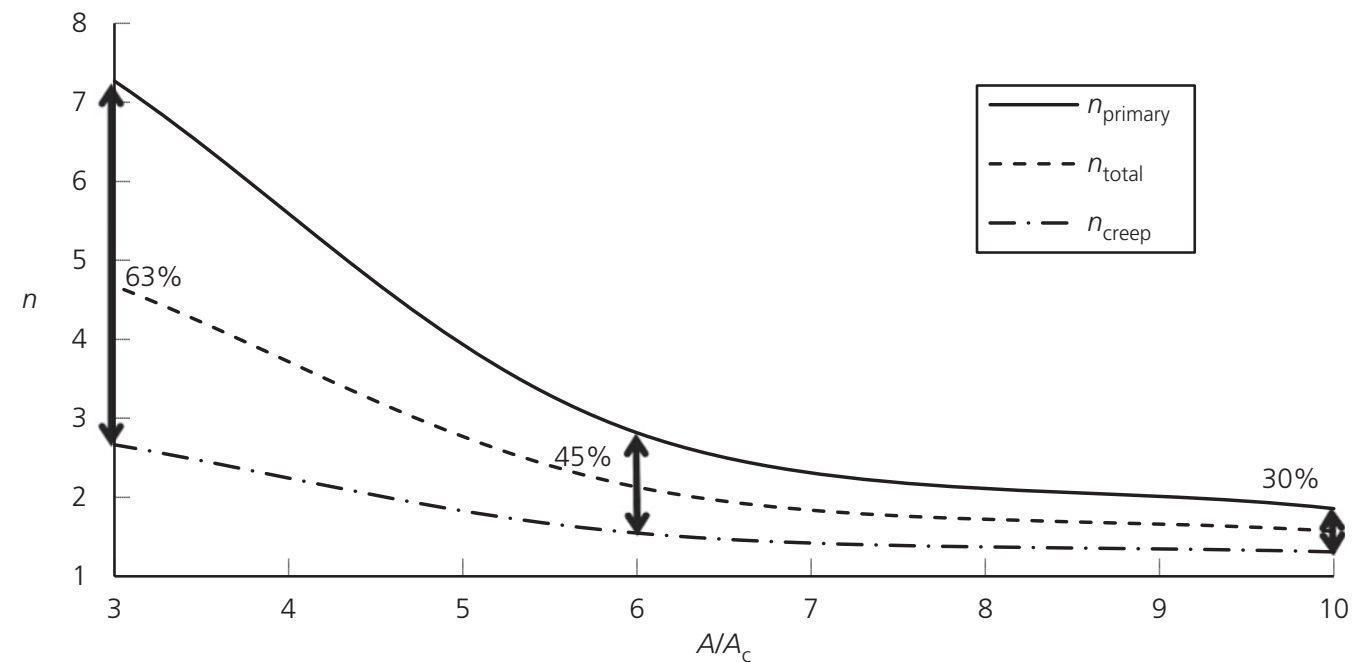

(a)

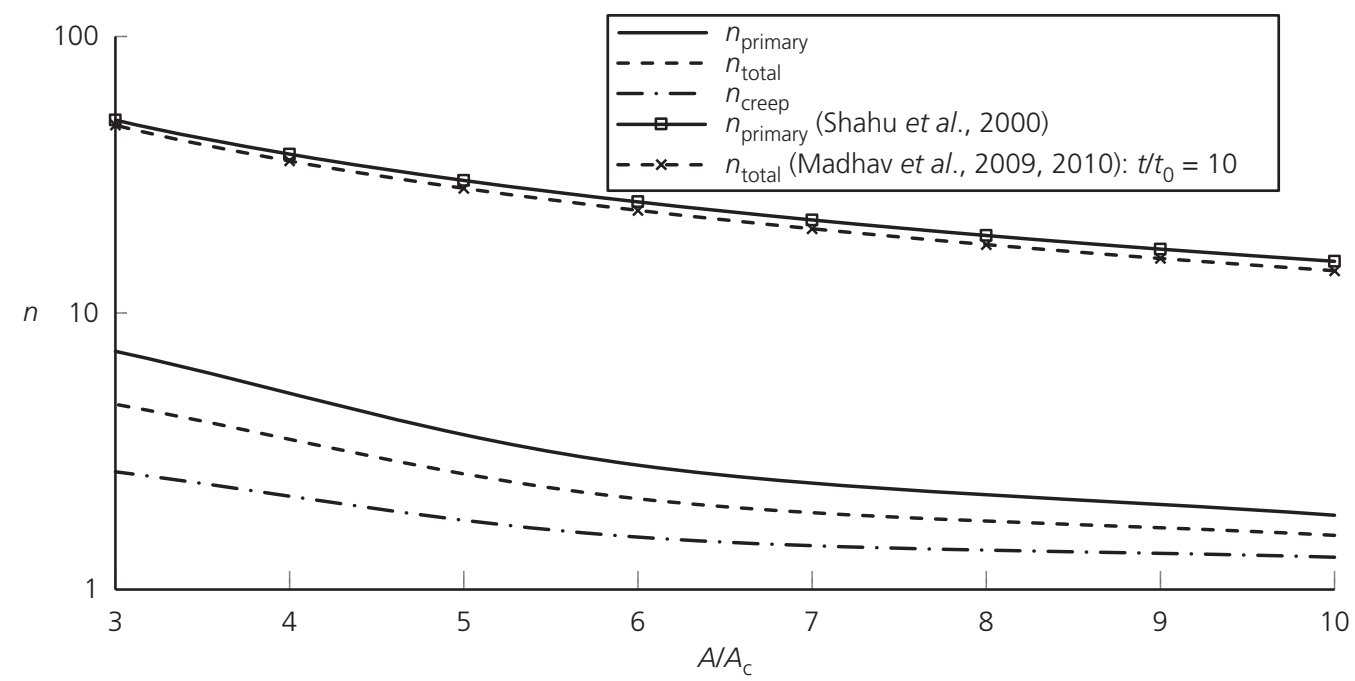

(b)

Figure 6. (a) $n_{\text {primary, }} n_{\text {total }}$ and $n_{\text {creep, }}$ and (b) comparison with Madhav et al. $(2009,2010)$ and Shahu et al. $(2000)$, $t / t_{0}=$ end time/EOP time

due to creep is more prevalent at closer spacings (i.e. $A / A_{\mathrm{c}}=3$ ). The mechanism of stress transfer from soil to column due to creep is in qualitative agreement with that proposed by Madhav et al. (2009, 2010); the Madhav et al. (2009, 2010) and Shahu et al. (2000) predictions are superimposed on Figures 7(c), 7(d) and 8(b). For the elasto-plastic columns modelled in this FE study, the stress transfer process results in additional column yielding and contributes to the lower 'total' settlement improvement factors for the 'with creep' case.

\subsection{Parametric study}

The parametric study assessed the effect of a range of different soil parameters $\left(C_{\mathrm{c}}\right.$ or $\lambda^{*}, C_{\mathrm{s}}$ or $\kappa^{*}, C_{\alpha}$ or $\left.\mu^{*}, K_{0}, \phi_{\mathrm{s}}^{\prime}\right)$ on $n_{\text {primary }}, n_{\text {total }}, n_{\text {creep }}$ and the average vertical effective stresses in the soil and column. The parameters of the crust layer are fixed throughout, with only the relevant parameter in the clay layer altered (the range of values examined span the range in Table 1). The influence of load level $\left(p_{\mathrm{a}}\right)$ is also investigated.

\subsubsection{Effect of $K_{0}$}

The effect of $K_{0}$ on $n_{\text {primary, }}, n_{\text {total }}$ and $n_{\text {creep }}$ is shown in Figure 9. The initial horizontal stresses generated in Plaxis increase as $K_{0}$ increases; intuitively the $n$ values should increase accordingly because the larger horizontal stresses provide more lateral support to resist column bulging. Figure 9 indicates that $n_{\text {primary }}$ increases as $K_{0}$ increases but $n_{\text {creep }}$ is relatively unchanged. Accordingly, percentage differences between $n_{\text {primary }}$ and $n_{\text {total }}$ increase as $K_{0}$ increases. The average vertical effective stresses $\left(\sigma_{y y}^{\prime}\right)$ in the soil and column after 100 years are compared in Figure 10 for the different $K_{0}$ values. As expected, the vertical stresses (with and without creep) are 


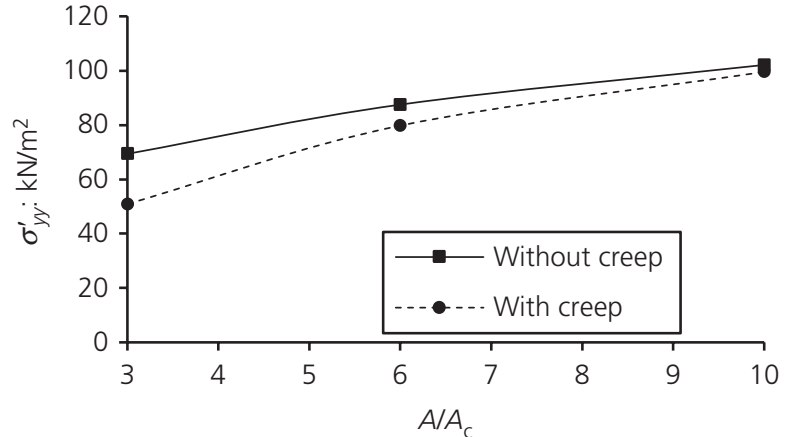

(a)

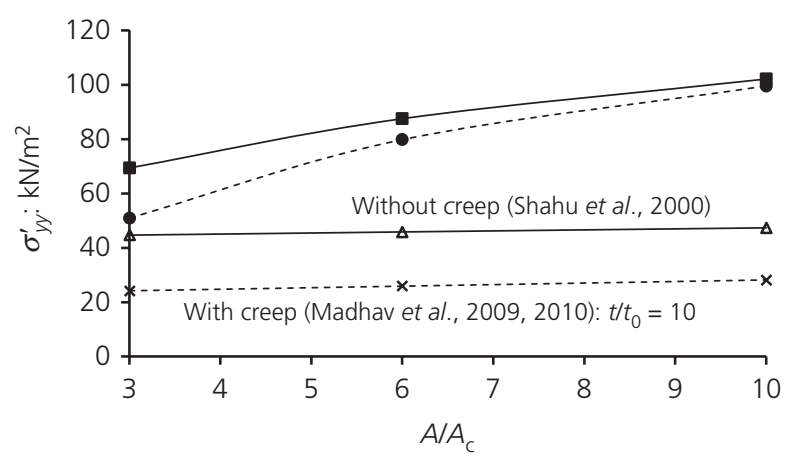

(c)

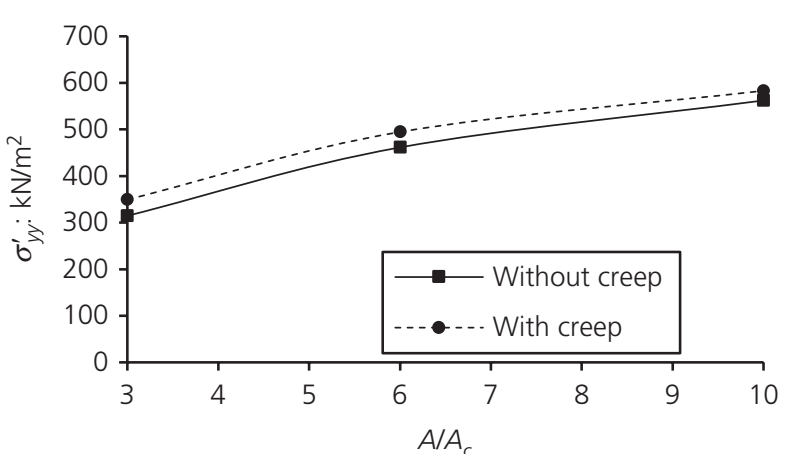

(b)

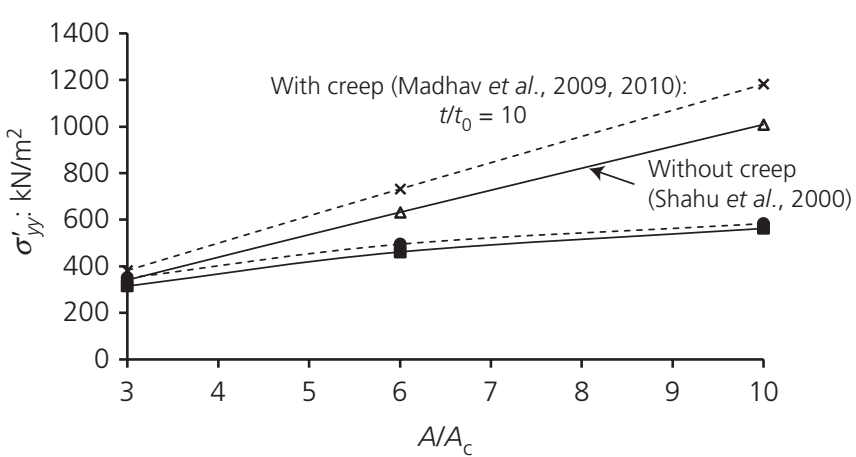

(d)

Figure 7. Average $\sigma_{y y}^{\prime}$ after 100 years: (a) soil, (b) stone column, (c) soil: comparison with Madhav et al. (2009, 2010) and Shahu et al. (2000) and (d) stone column: comparison with Madhav et al. $(2009,2010)$ and Shahu et al. $(2000), t / t_{0}=$ end time/EOP time

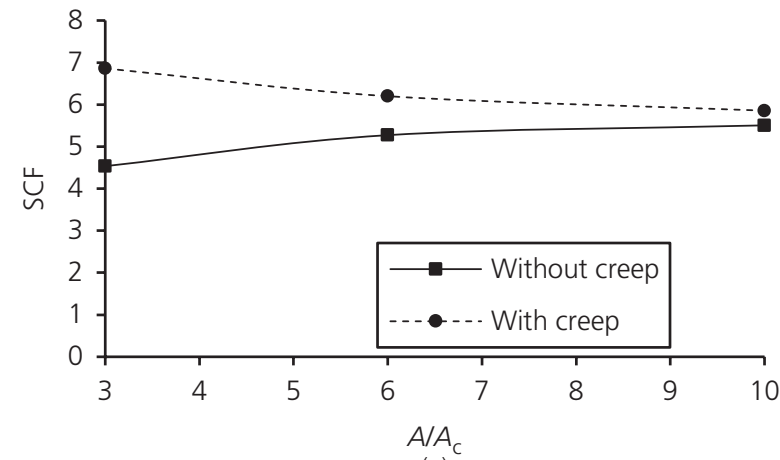

(a)

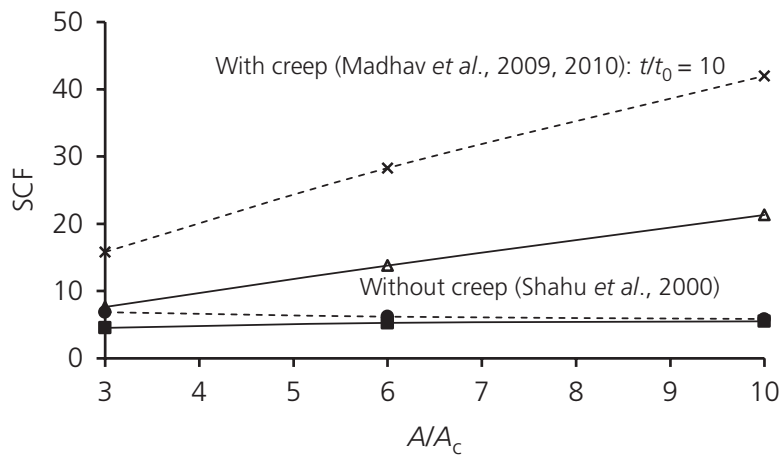

(b)

Figure 8. (a) SCFs after 100 years and (b) SCFs after 100 years: comparison with Madhav et al. $(2009,2010)$ and Shahu et al. (2000), $t / t_{0}=$ end time/EOP time

similar for all three $K_{0}$ values, with a maximum difference of $\sim 5 \%$ over the range of $K_{0}$ values considered for the "without creep' case.

\subsubsection{Effect of $\mu^{*}$}

In this parametric study, the range of $\mu^{*}$ values considered have varied from half to double that of the base case, resulting in creep ratios, $\left(\lambda^{*}-\kappa^{*}\right) / \mu^{*}$, of $42 \cdot 8$ and $10 \cdot 7$, respectively, spanning the range in Figure 2. The creep ratio, $\left(\lambda^{*}-\kappa^{*}\right) / \mu^{*}=5$, reported by Lopes (2011) for the soft soils of the Tagus Basin in Portugal seems to be an outlier because the high $\mu^{*} / \lambda^{*}$ ratio of $0 \cdot 146$ is out of kilter with the correlation proposed by Mesri and Godlewski (1977) encompassing a variety of natural soils.

The findings in Figure 11 indicate that $n_{\text {total }}$ reduces as $\mu^{*}$ increases because the weighted effect of creep has more influence (the $n_{\text {primary }}$ values are unaffected). It is interesting to note that, at close spacings, the $n_{\text {creep }}$ values increase marginally for lower $\mu^{*}$ values because full yielding of the granular material does not take place. The average vertical effective stresses in the soil and column after 100 years for the different $\mu^{*}$ values are compared with the 'without creep' case in Figure 12 . For higher $\mu^{*}$ values, additional stress is unloaded 


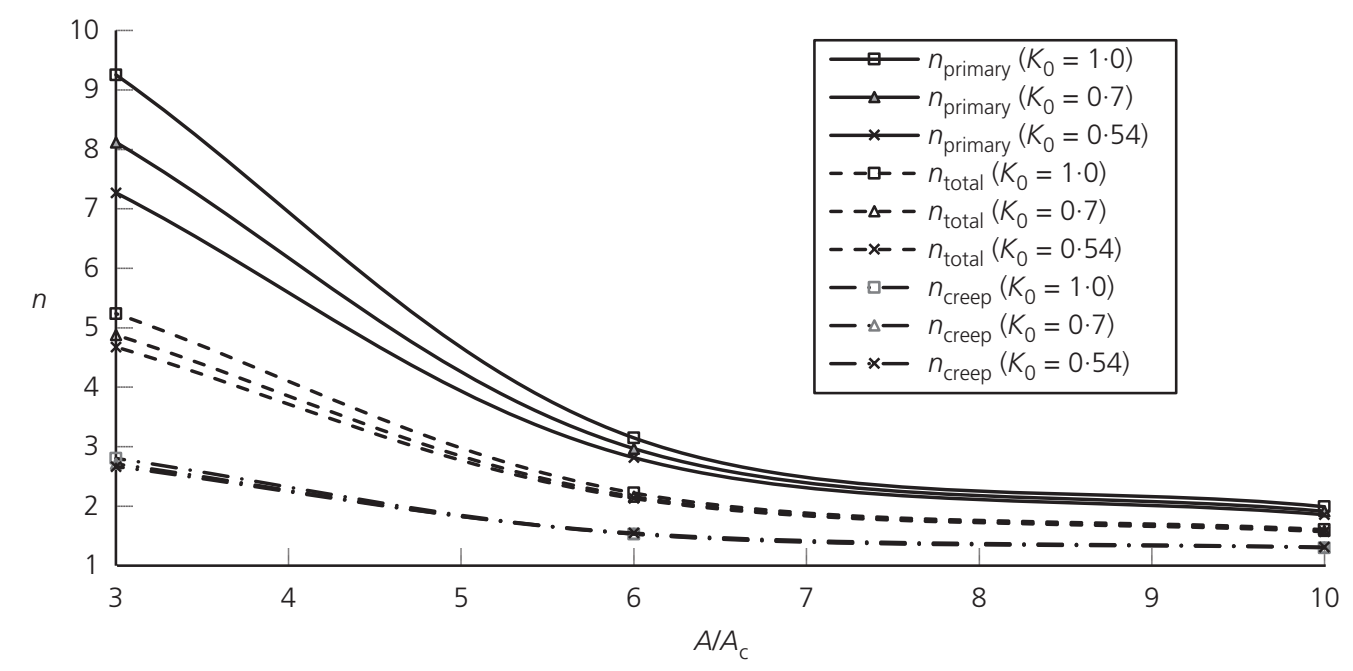

Figure 9. Effect of $K_{0}$ on $n_{\text {primary, }} n_{\text {total }}$ and $n_{\text {creep }}$

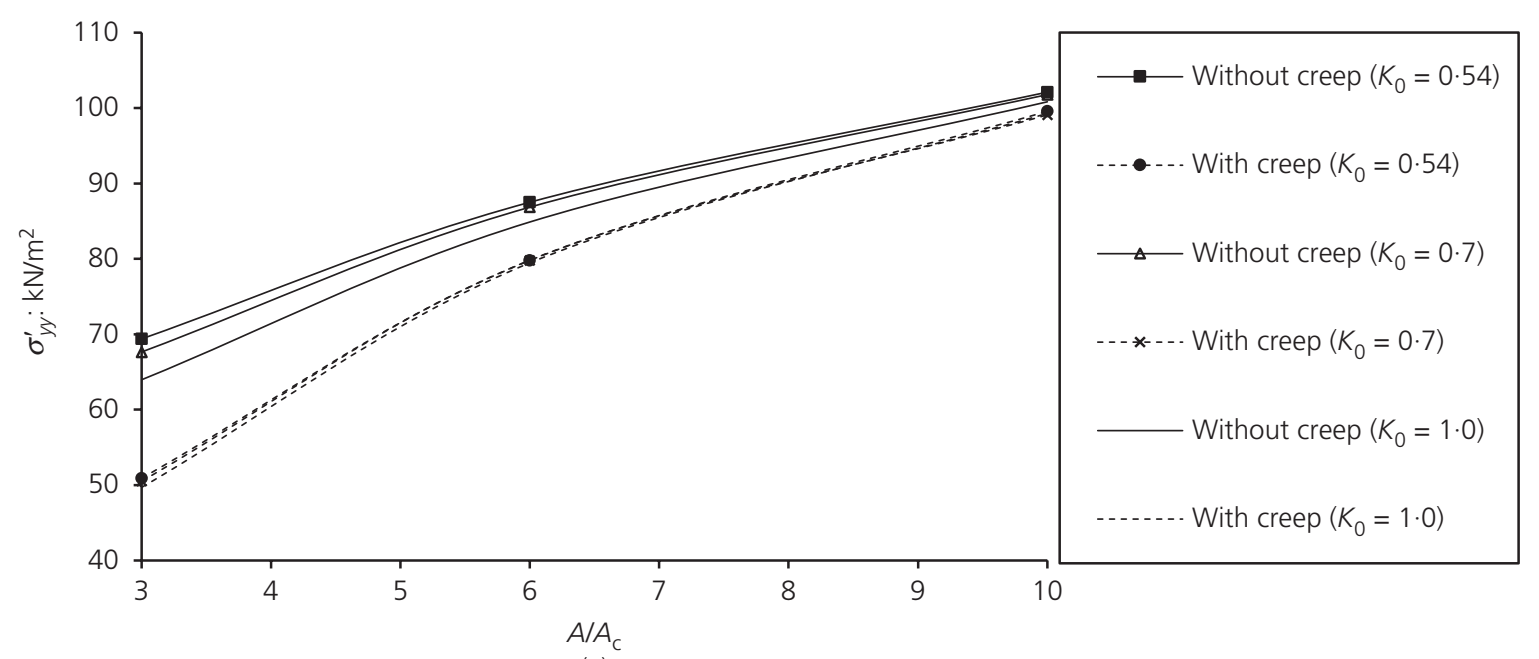

(a)

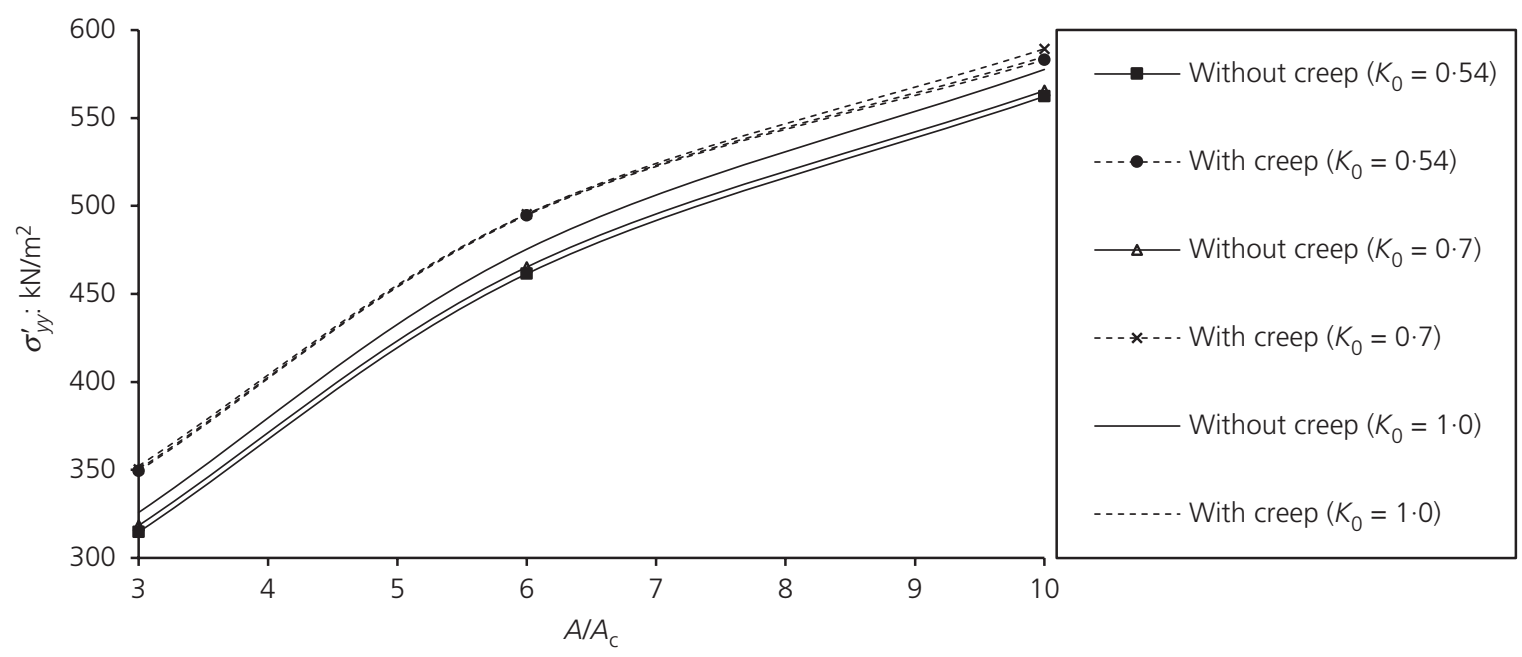

(b)

Figure 10. Effect of $K_{0}$ on average $\sigma_{y y}^{\prime}$ after 100 years: (a) soil and (b) stone column 


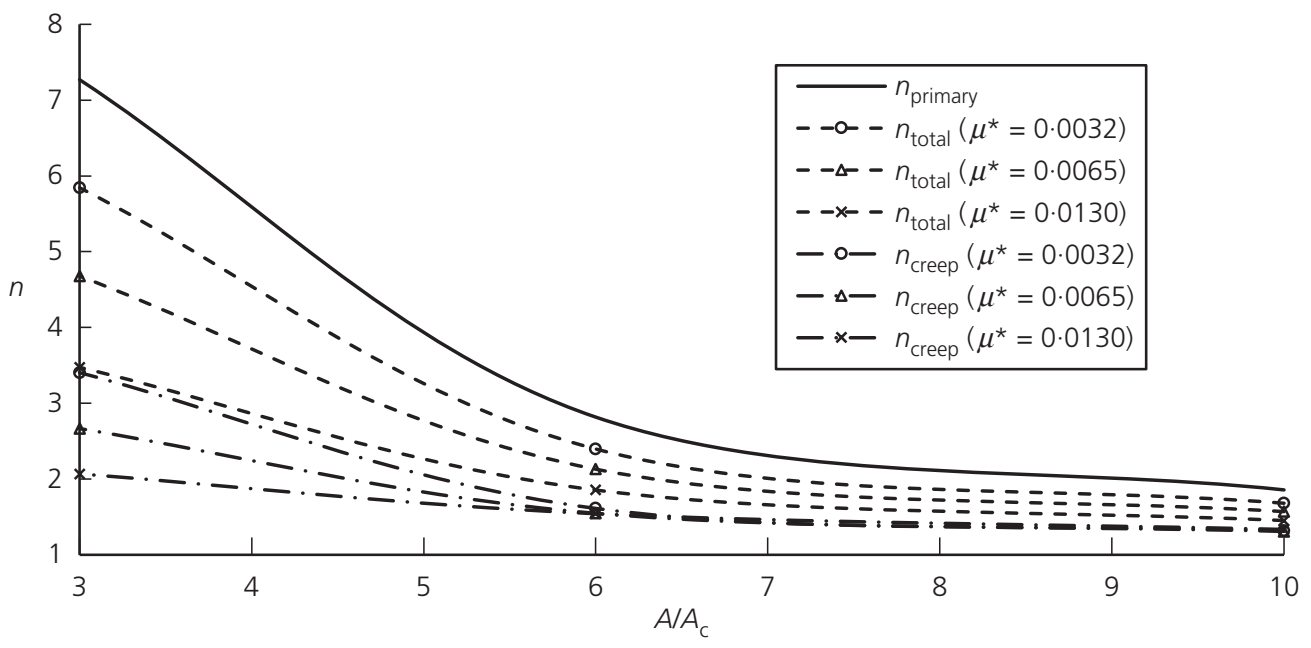

Figure 11. Effect of $\mu^{*}$ on $n_{\text {total }}$ and $n_{\text {creep }}$

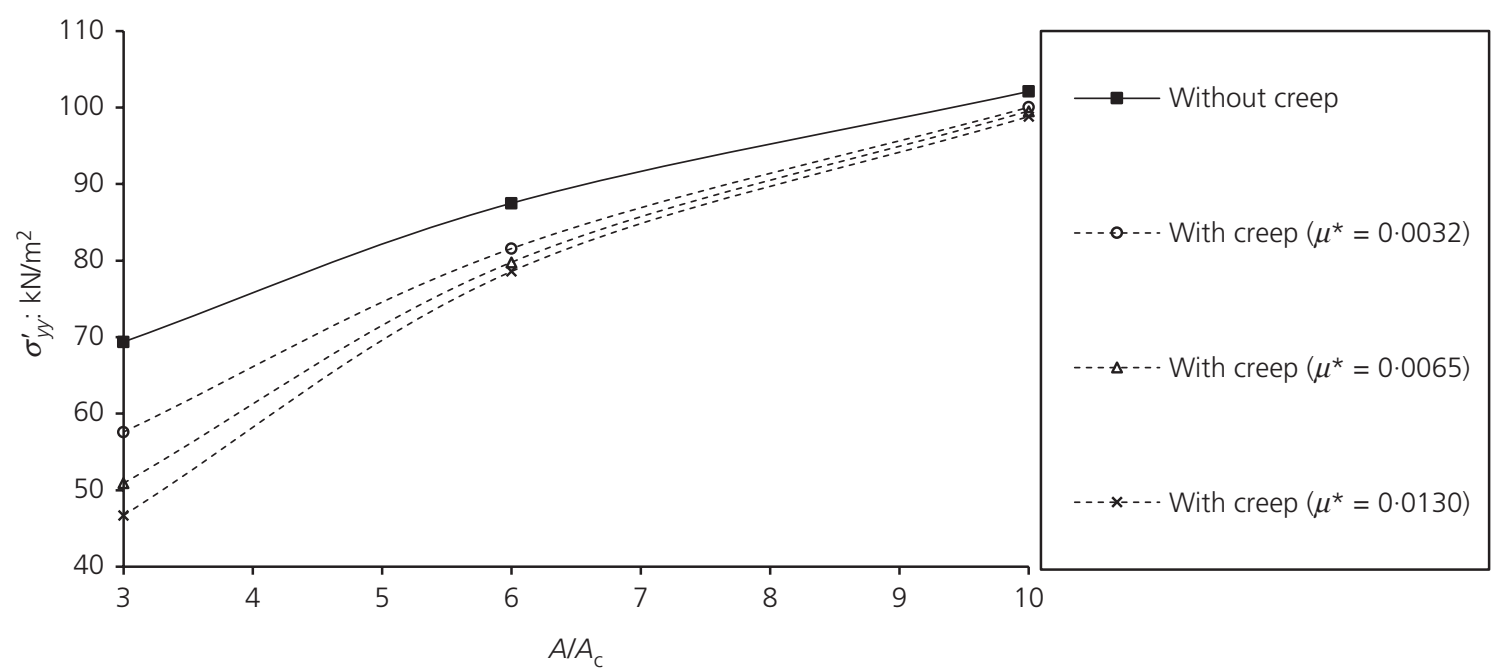

(a)

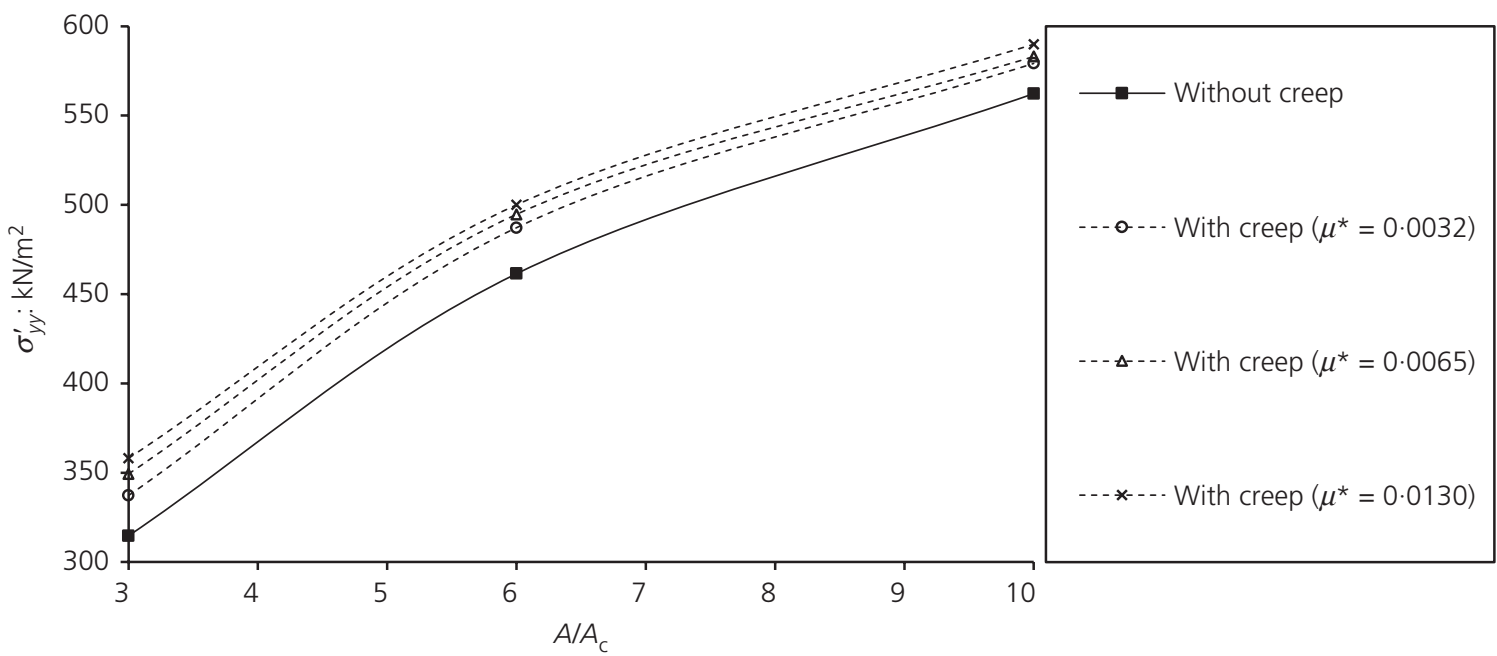

(b)

Figure 12. Effect of $\mu^{\star}$ on average $\sigma_{y y}^{\prime}$ after 100 years: (a) soil and (b) stone column 


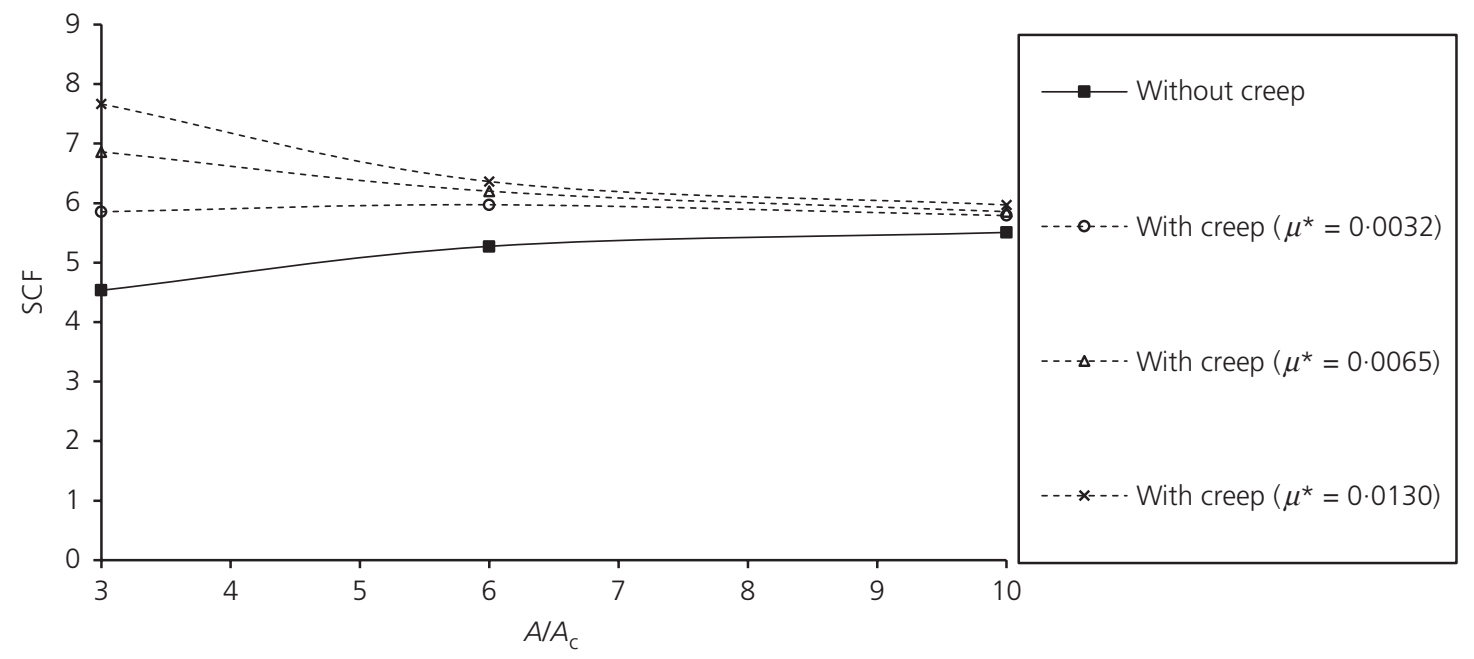

Figure 13. Effect of $\mu^{*}$ on the SCFs after 100 years

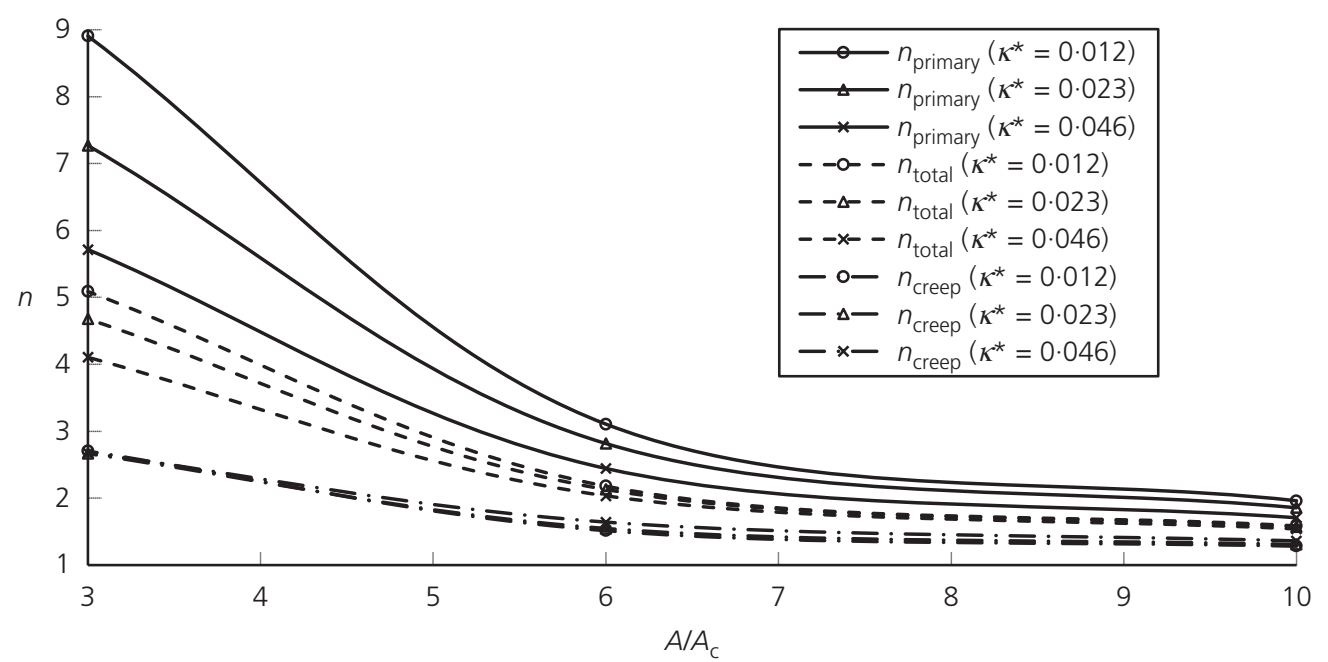

Figure 14. Effect of $\kappa^{\star}$ on $n_{\text {primary, }} n_{\text {total }}$ and $n_{\text {creep }}$

from the soil (Figure 12(a)) and transferred to the column (Figure 12(b)). Consequently, the SCFs increase as $\mu^{*}$ increases (Figure 13). These trends are in qualitative agreement with those of Madhav et al. (2009, 2010).

\subsubsection{Effect of $\kappa^{*}$}

The effects of both halving and doubling the default value of $\kappa^{*}$ (to 0.012 and 0.046 ) on $n_{\text {primary }}, n_{\text {total }}$ and $n_{\text {creep }}$ are shown in Figure 14. Again, these $\kappa^{*}$ values are towards the lower and higher end, respectively, of those quoted in Table 1. Lower $\kappa^{*}$ values result in higher $n_{\text {primary }}$ and $n_{\text {total }}$ values, although the latter do not increase to the same extent as the former because the $n_{\text {creep }}$ values are relatively unaffected by $\kappa^{*}$. The higher $n$ values at lower $\kappa^{*}$ values can be explained as follows: for lower $\kappa^{*}$ values, the settlements of untreated and treated ground reduce. However, the settlement of untreated ground will only reduce marginally (lightly overconsolidated soil), whereas the settlement of treated ground will experience more of a reduction as the columns reduce the stress carried by the soil (resulting in an overconsolidation effect) so that $\kappa^{*}$ has more of an influence. Accordingly, the denominator ( $n=\delta_{\text {untreated }} / \delta_{\text {treated }}$ ) reduces more than the numerator and so $n$ increases.

The average vertical effective stresses in the soil and column for the three different $\kappa^{*}$ values without and with creep are plotted in Figure 15. The amount of stress transferred from the soil to the column due to creep is relatively unaffected by $\kappa^{*}$; this indicates that the load transfer process from soil to column due to creep is not influenced by the unload-reload index.

\subsubsection{Effect of $\lambda^{*}$}

The effect of $\lambda^{*}$ on $n_{\text {primary, }} n_{\text {total }}$ and $n_{\text {creep }}$ is shown in Figure 16. Values of $\lambda^{*}>0 \cdot 162$ have not been studied as the soil profile would be too soft to provide sufficient lateral 


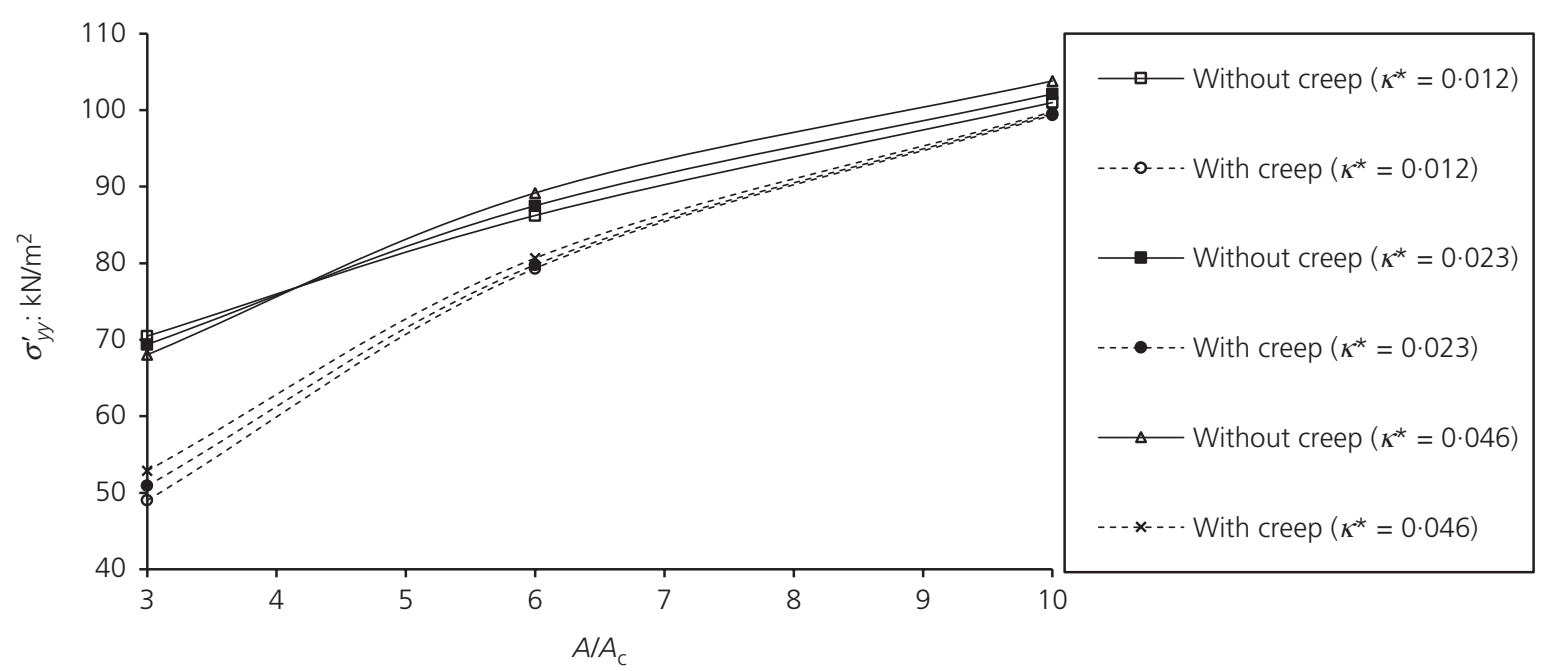

(a)

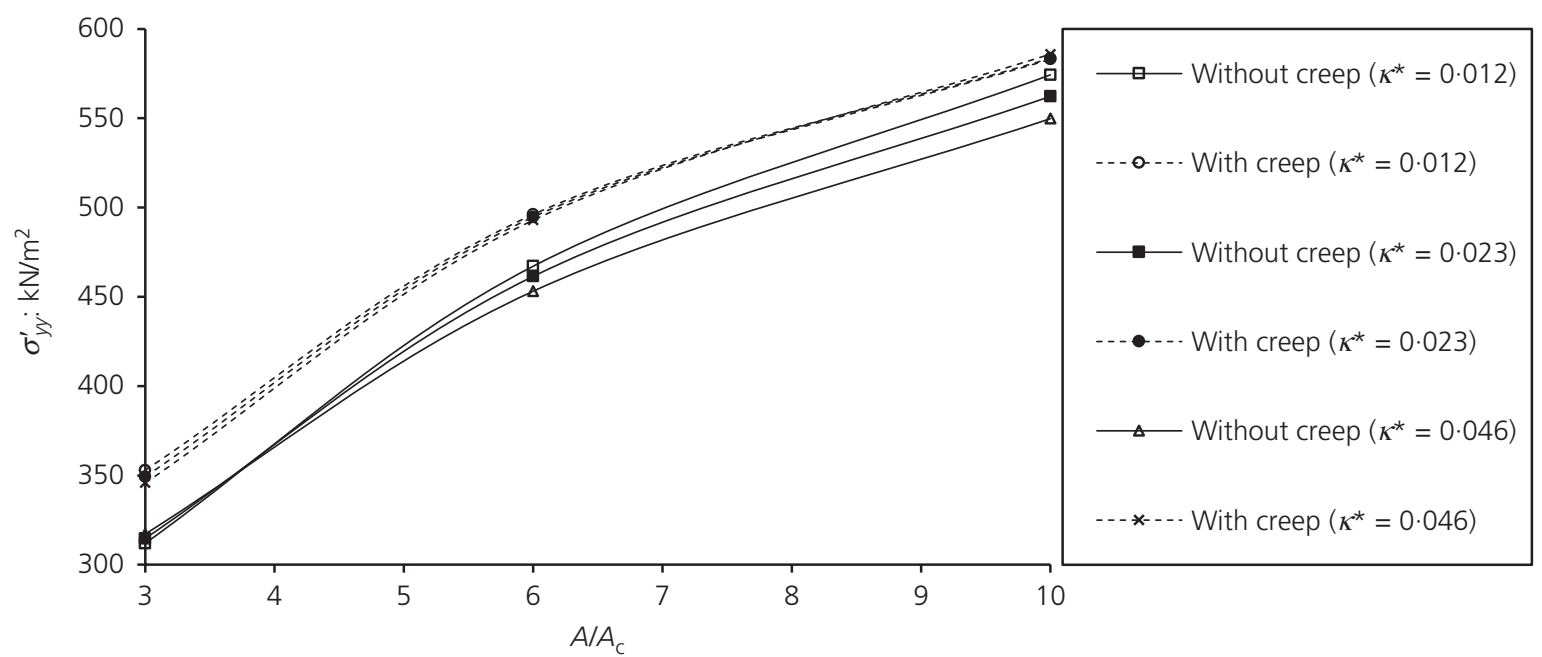

(b)

Figure 15. Effect of $\kappa^{\star}$ on average $\sigma_{y y}^{\prime}$ after 100 years: (a) soil and (b) stone column

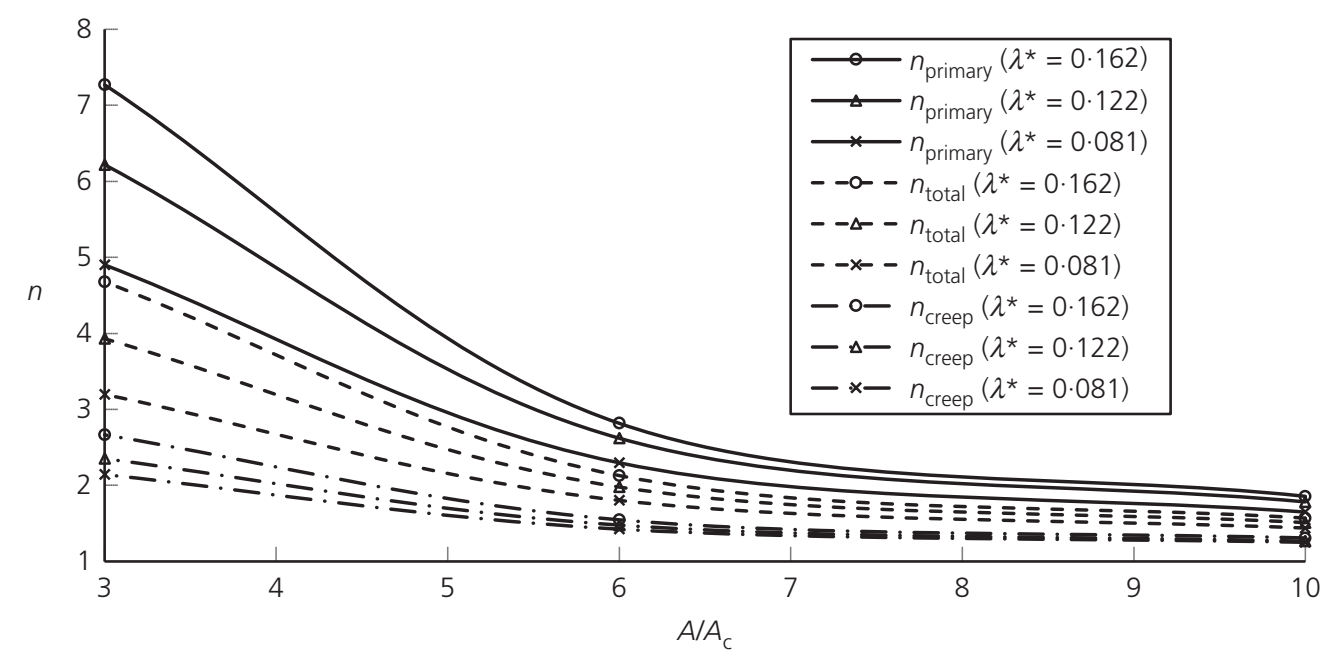

Figure 16. Effect of $\lambda^{*}$ on $n_{\text {primary, }} n_{\text {total }}$ and $n_{\text {creep }}$ 


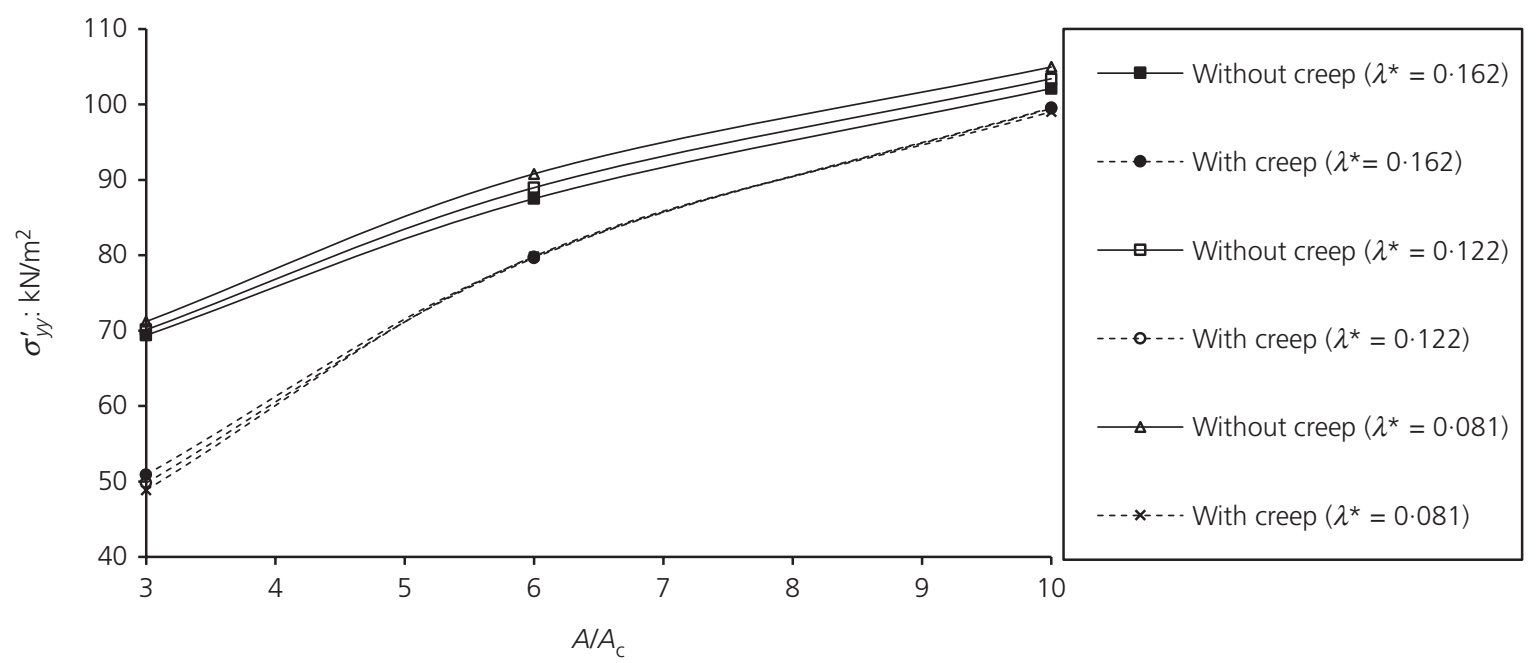

(a)

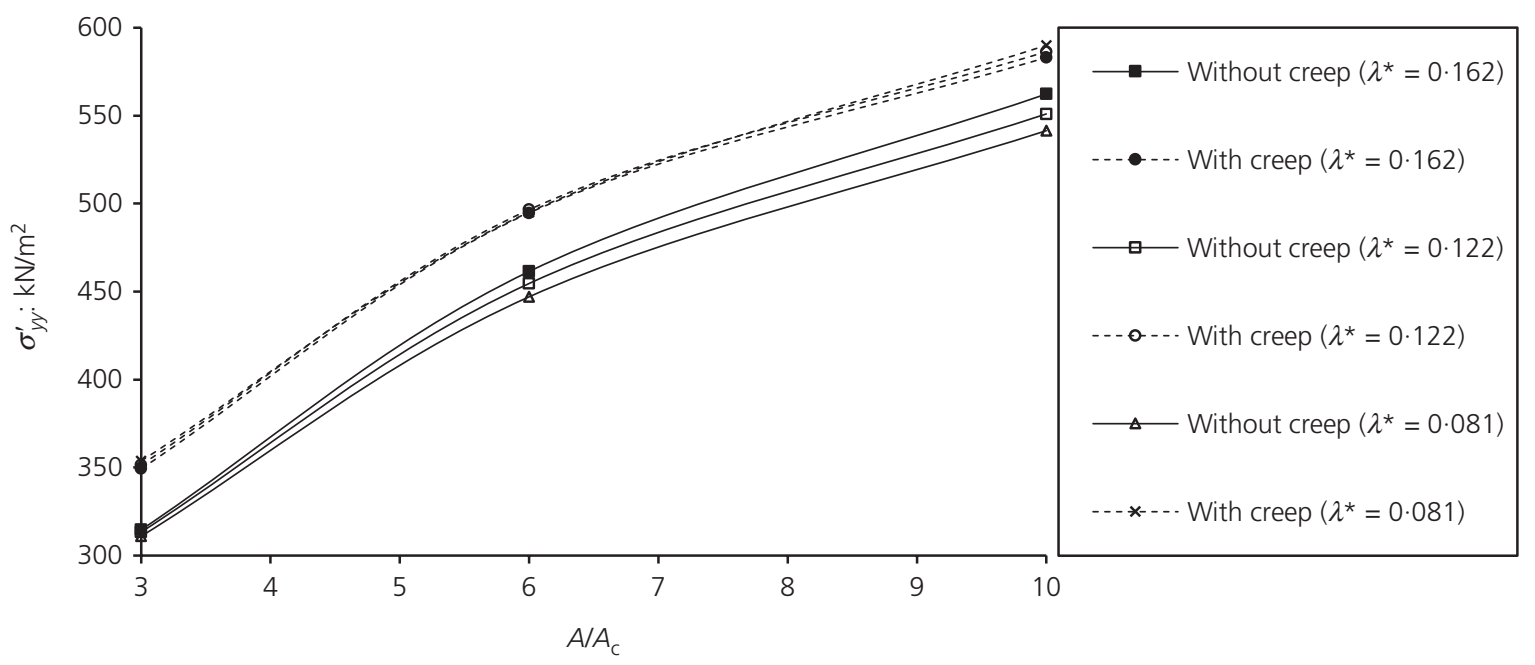

(b)

Figure 17. Effect of $\lambda^{*}$ on average $\sigma_{y y}^{\prime}$ after 100 years: (a) soil and (b) stone column

support for granular columns without some form of geotextile encasement. Lower $\lambda^{*}$ values correspond to higher oedometric soil moduli; accordingly $E_{\mathrm{c}} / E_{\mathrm{s}}$ reduces, resulting in lower $n$ values. The average vertical effective stresses in the soil and column after 100 years for the different $\lambda^{*}$ values, compared in Figure 17 , indicate that the stresses are relatively independent of $\lambda^{*}$ for the range of values considered in this study (softer creep-prone soils).

\subsubsection{Effect of $\phi_{\mathrm{s}}^{\prime}$}

The friction angle of the Bothkennar Carse clay $\left(\phi_{\mathrm{s}}^{\prime}=34^{\circ}\right)$ is higher than that of other soft clays reported in the literature (Table 1), attributable to the significant amount of angular silt particles and the relatively high organic content (Allman and Atkinson, 1992). The effect of $\phi_{\mathrm{s}}^{\prime}$ on $n$ (in the range $26^{\circ}-34^{\circ}$ ) is shown in Figure 18; both $n_{\text {primary }}$ and $n_{\text {total }}$ increase marginally as $\phi_{\mathrm{s}}^{\prime}$ increases ( $n_{\text {creep }}$ is unaffected). The increases are attributable to an increased $K_{0}$, which is automatically updated when $\phi_{\mathrm{s}}^{\prime}$ is changed (e.g. Equation 13 with $K_{0}^{\mathrm{nc}}=1-\sin \phi_{\mathrm{s}}^{\prime}$ ). The average vertical effective stresses in the soil and column after 100 years are unaffected (e.g. Figure 19 (as was the case for the different $K_{0}$ values, see Figure 10)).

\subsubsection{Effect of $p_{a}$}

The effect of load level on $n_{\text {primary }}, n_{\text {total }}$ and $n_{\text {creep }}$ is presented in Figure 20. The range of load levels considered is based on the ranges quoted by Castro and Sagaseta (2009), Ellouze and Bouassida (2009) and Mitchell and Huber (1985). At lower load levels, $n$ values are larger; stone columns are more effective because there is less yielding. As a result, $n_{\text {creep }}$ values at $p_{\mathrm{a}}=50 \mathrm{kPa}$ are larger than those at either $p_{\mathrm{a}}=100 \mathrm{kPa}$ or $p_{\mathrm{a}}=150 \mathrm{kPa}$, which are almost the same. The average vertical effective stresses in both the soil and column increase as $p_{\text {a }}$ increases (e.g. Figure 21, after 100 years). The stress 


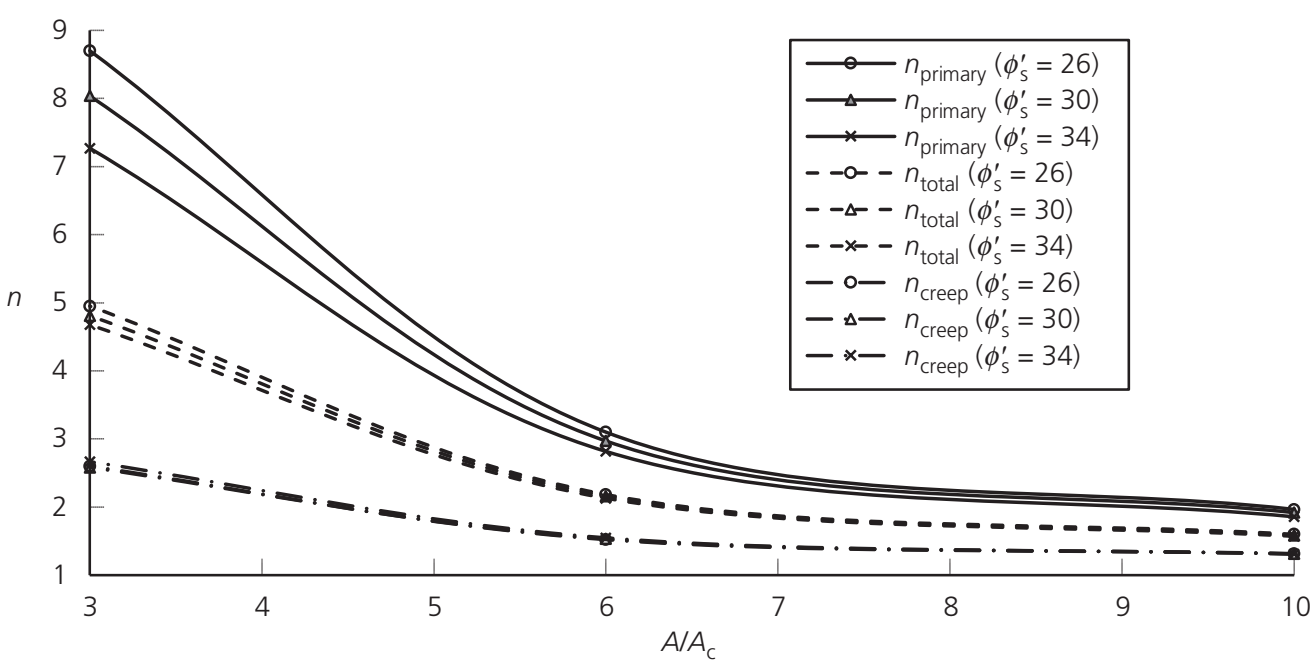

Figure 18. Effect of $\phi_{\mathrm{s}}^{\prime}$ on $n_{\text {primary, }} n_{\text {total }}$ and $n_{\text {creep }}$

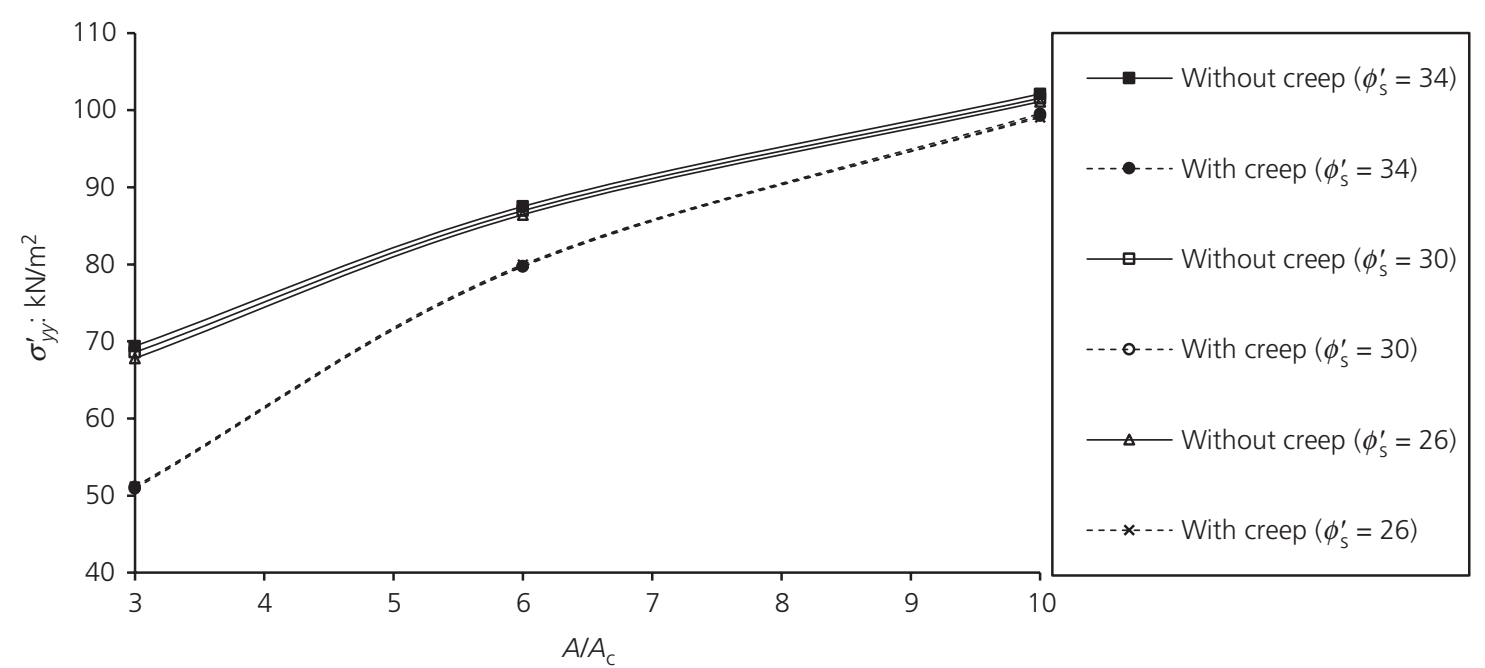

(a)

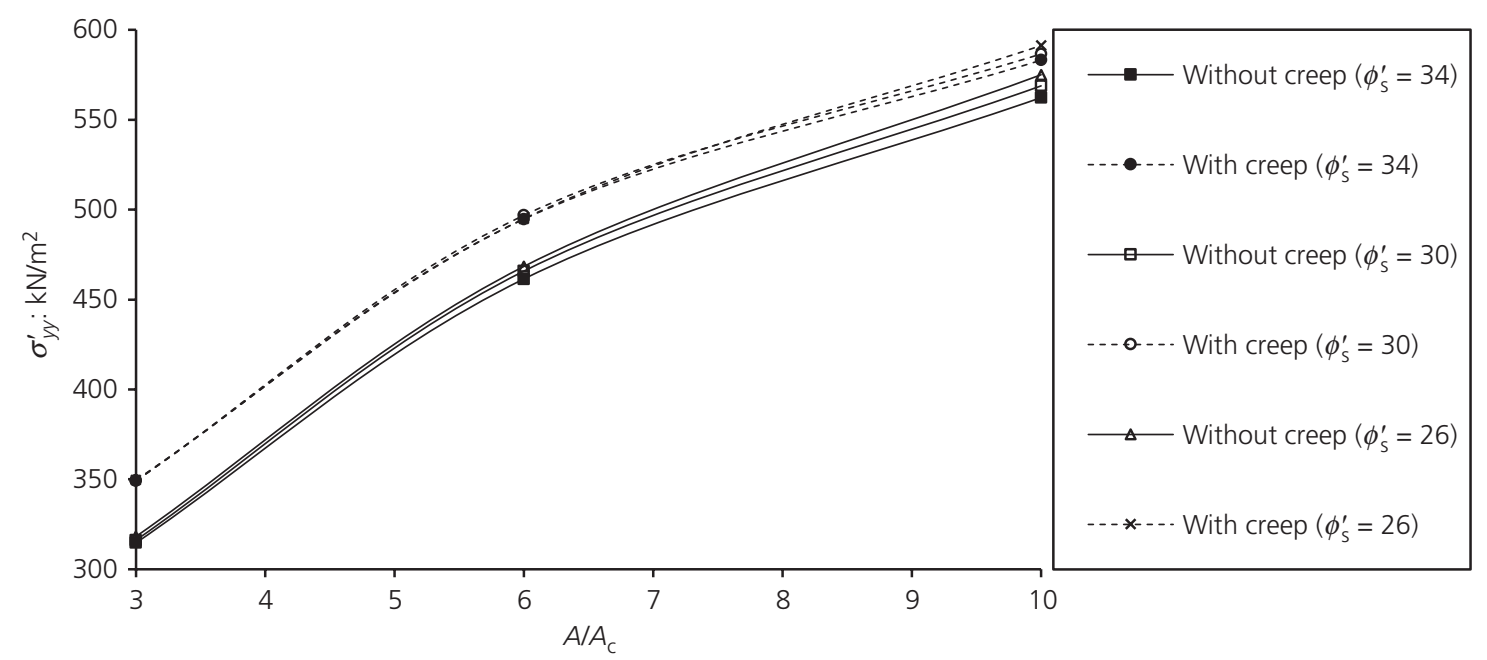

(b)

Figure 19. Effect of $\phi_{s}^{\prime}$ on average $\sigma_{y y}^{\prime}$ after 100 years: (a) soil, (b) stone column 


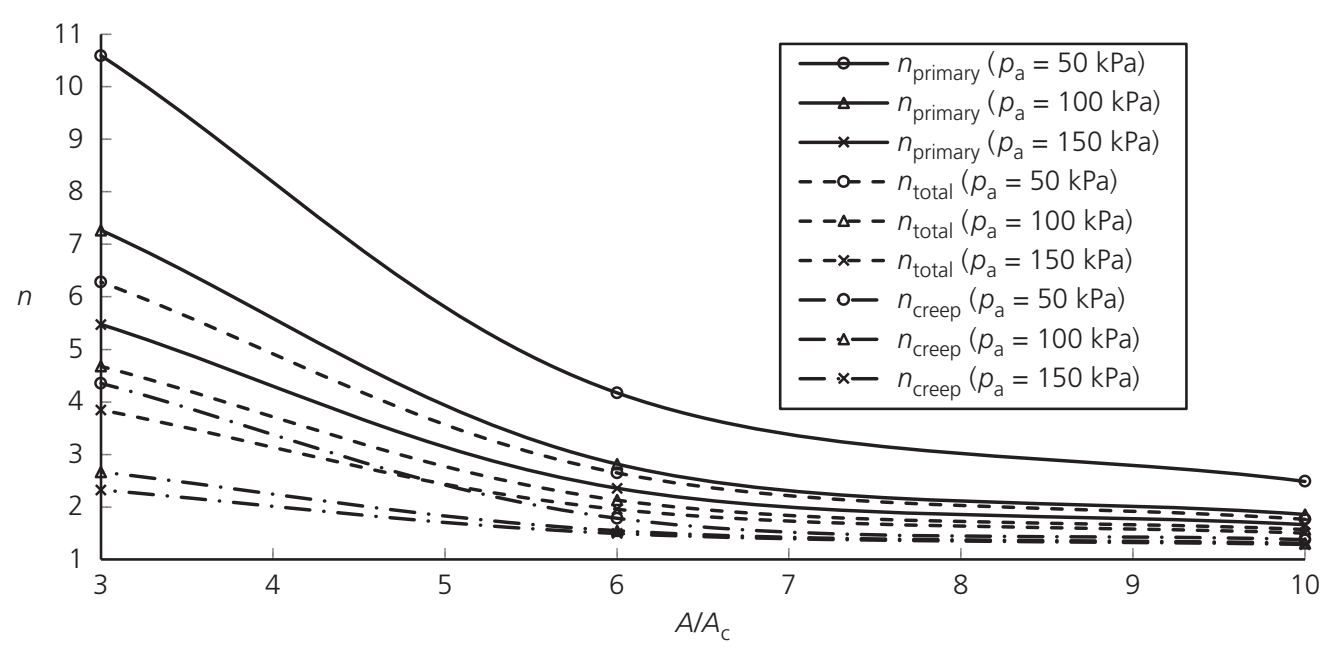

Figure 20. Effect of $p_{a}$ on $n_{\text {primary, }} n_{\text {total }}$ and $n_{\text {creep }}$

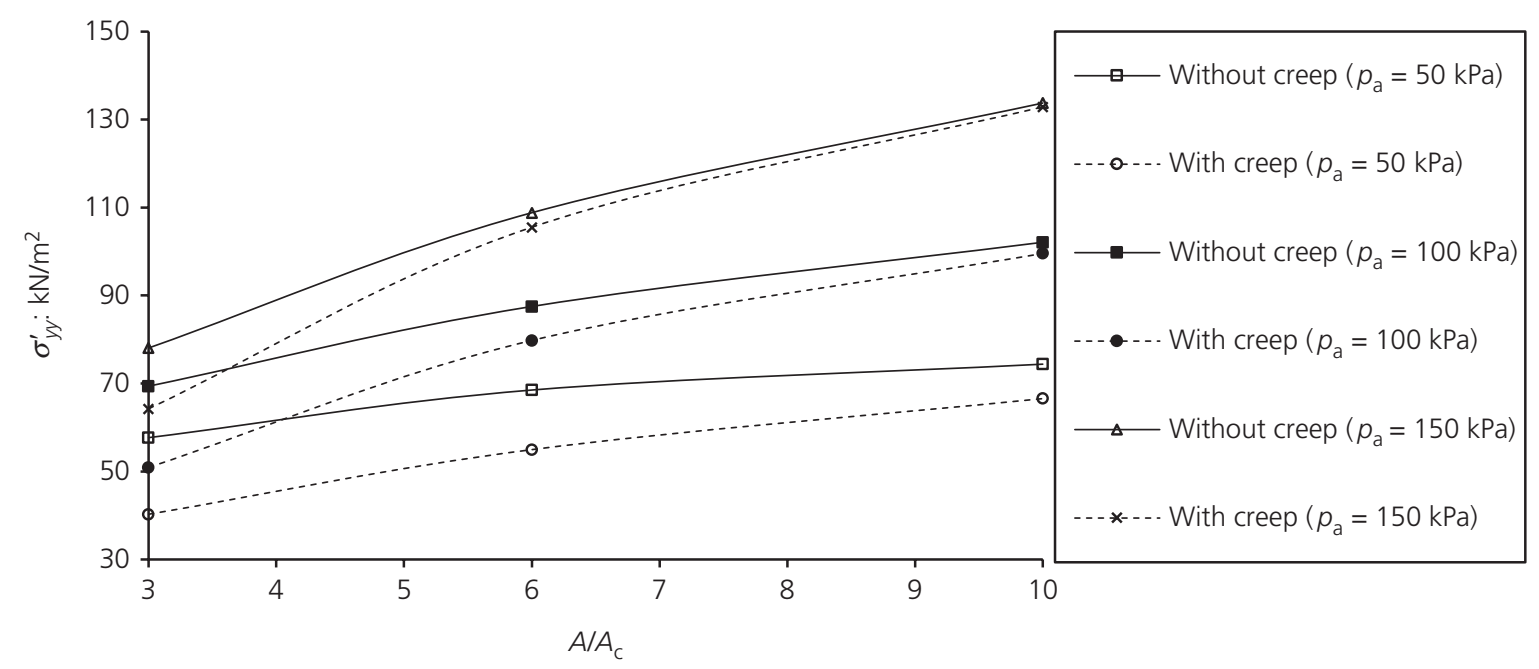

(a)

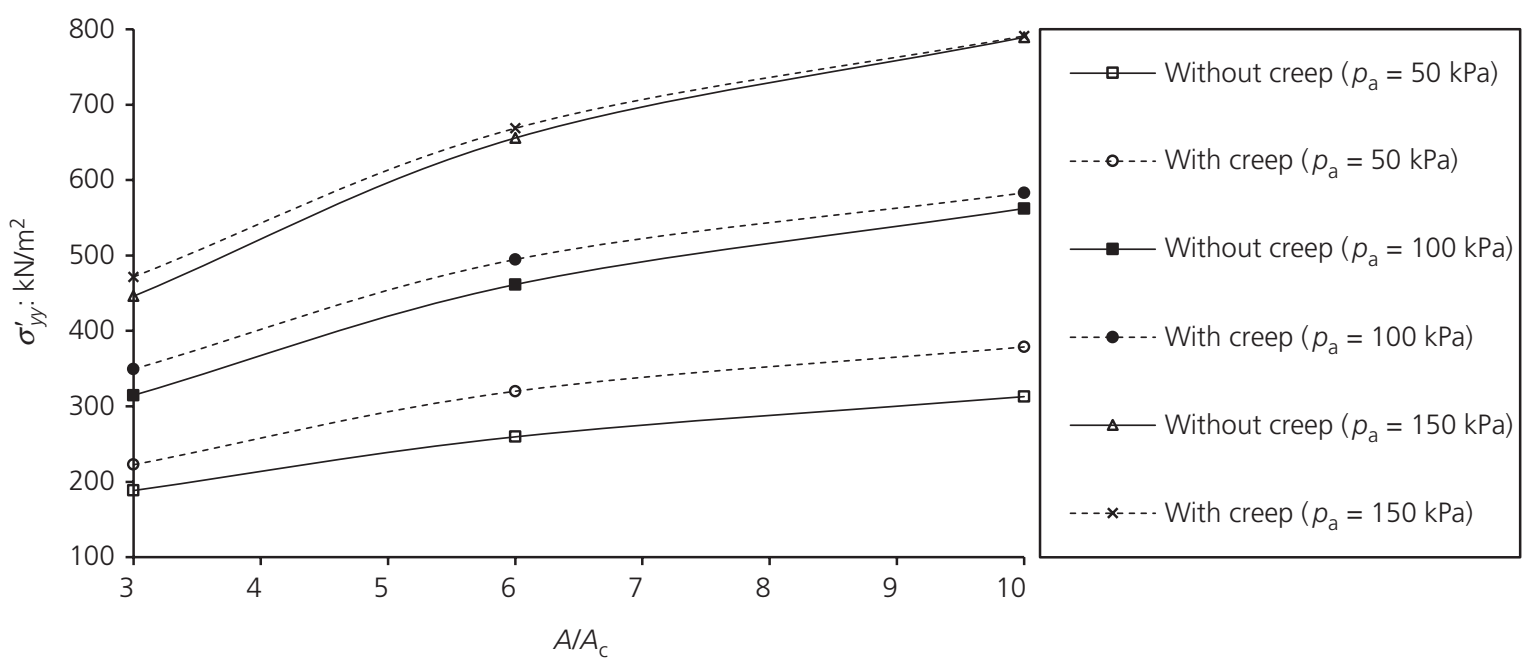

(b)

Figure 21. Effect of $p_{a}$ on average $\sigma_{y y}^{\prime}$ after 100 years: (a) soil and (b) stone column 


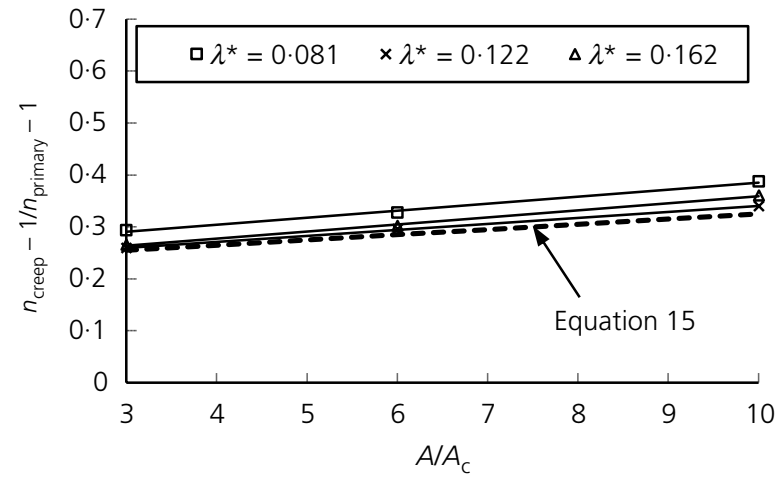

(a)

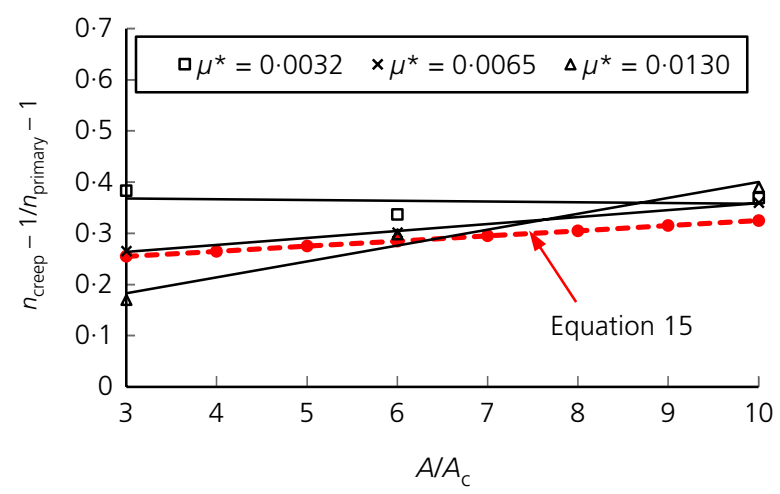

(c)

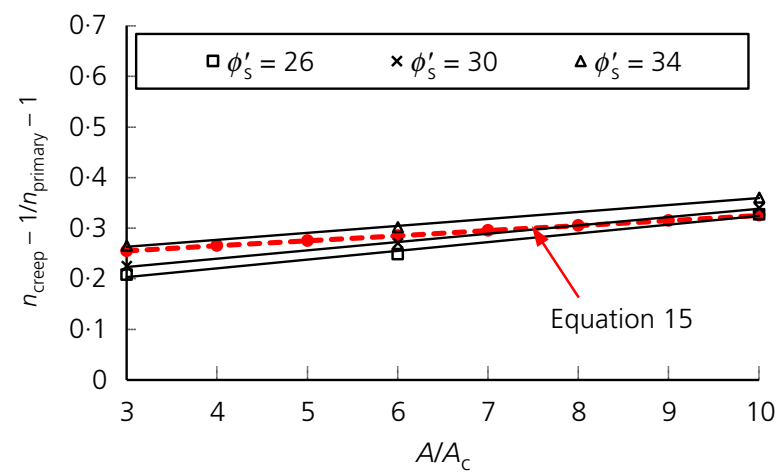

(e)

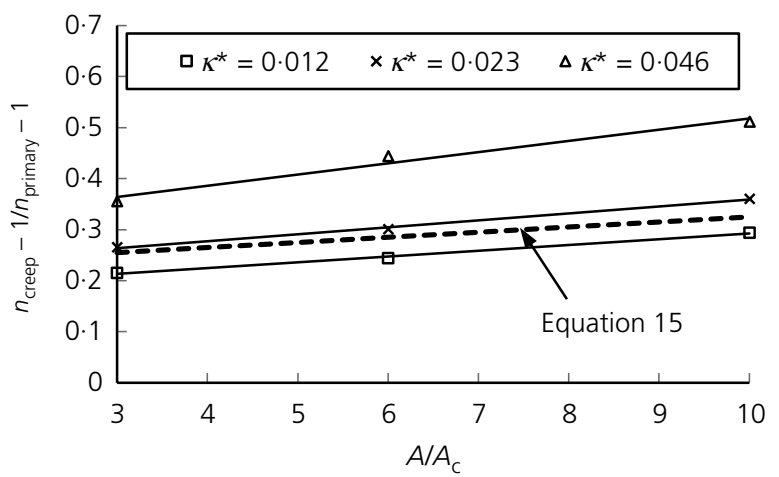

(b)

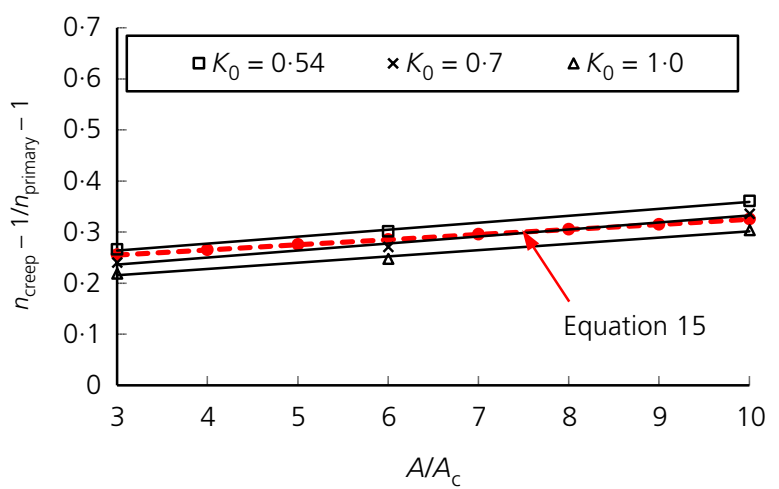

(d)

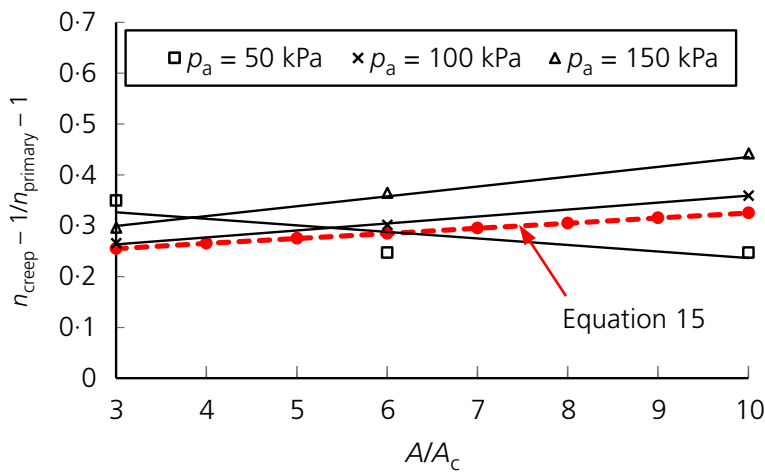

(f)

Figure 22. $\left(n_{\text {creep }}-1\right) /\left(n_{\text {primary }}-1\right)$ against $A / A_{c}$ : (a) influence of $\lambda^{*}$, (b) influence of $\kappa^{*}$, (c) influence of $\mu^{*}$, (d) influence of $K_{0}$, (e) influence of $\phi_{\mathrm{s}}^{\prime}$ and (f) influence of $p_{\mathrm{a}}$

transfer process from soil to column due to creep is more significant at $p_{\mathrm{a}}=50 \mathrm{kPa}$ than at $p_{\mathrm{a}}=100 \mathrm{kPa}$ or $p_{\mathrm{a}}=150 \mathrm{kPa}$. At $p_{\mathrm{a}}=50 \mathrm{kPa}$ without creep, the column has not fully yielded and so there is more scope for stress transfer from soil to column due to creep.

\section{Incorporating creep into the vibro-replacement design process}

The FE output in this paper has been used to develop an empirical design approach to incorporate creep into the vibro-replacement design process. This approach, developed for end-bearing columns, is closed form, and can be used in conjunction with any pre-existing primary settlement design method, although as mentioned in Section 2.2, the methods derived by Castro and Sagaseta (2009) and Pulko et al. (2011) are recommended.

The FE output presented in Section 5 is presented as a ratio of $\left(n_{\text {creep }}-1\right) /\left(n_{\text {primary }}-1\right)$ against $A / A_{\mathrm{c}}$ in Figure 22 . The ratio $\left(n_{\text {creep }}-1\right) /\left(n_{\text {primary }}-1\right)$ is used instead of $\left(n_{\text {creep }}\right) /\left(n_{\text {primary }}\right)$ to ensure that the value of $n_{\text {creep }}$ predicted using Equation 15 will always be $>1$. In the interest of simplicity, the formula 
developed for $n_{\text {creep }}$ is a function of $A / A_{\mathrm{c}}$ only. The ratio is lowest at $A / A_{\mathrm{c}}=3$ (i.e. larger differences between $n_{\text {primary }}$ and $n_{\text {creep }}$ ) and increases as $A / A_{\mathrm{c}}$ increases. In general, Equation 15 (superimposed on Figure 22) provides a good and slightly conservative match to the FE data in the majority of cases; the deviation at $p_{\mathrm{a}}=50 \mathrm{kPa}$ occurs due to the absence of yielding. This design equation will only be applicable to creep-prone soils $\left(\lambda^{*} \gtrsim 0 \cdot 8\right.$, see Table 1$)$, for which the influence of modular ratio (i.e. $\lambda^{*}$ ) is small.

15. $\frac{\left(n_{\text {creep }}-1\right)}{\left(n_{\text {primary }}-1\right)}=0 \cdot 225+0 \cdot 01\left(A / A_{\mathrm{c}}\right)$

Having established an expression for $n_{\text {creep }}, n_{\text {total }}$ can be calculated as a weighted average of $n_{\text {primary }}$ as predicted by a preexisting settlement design method and $n_{\text {creep }}$ (from Equation 15), as shown in the following equation

16.

$$
n_{\text {total }}=n_{\text {primary }} w_{1}+n_{\text {creep }} w_{2}
$$

where $w_{1}$ and $w_{2}$ are weighting factors dependent on the percentages of primary and creep settlement anticipated in an equivalent untreated profile, which depend on the creep ratio, $\left(\lambda^{*}-\kappa^{*}\right) / \mu^{*}$, of the untreated soil profile. The percentages can be worked out using the 1D compression formulae outlined in Equation 17 (for $\left.\sigma_{0}+\Delta \sigma<\sigma_{\mathrm{p}}\right)$, Equation $18\left(\sigma_{0}+\Delta \sigma>\sigma_{\mathrm{p}}\right)$ and Equation 19 (creep component), where $\Delta \sigma$ denotes the load, $H$ is the layer thickness.

17. $\delta=H \frac{C_{\mathrm{s}}}{1+e_{0}} \log \left(\frac{\sigma_{0}+\Delta \sigma}{\sigma_{0}}\right)$

18. $\delta=H \frac{C_{\mathrm{s}}}{1+e_{0}} \log \left(\frac{\sigma_{\mathrm{p}}}{\sigma_{0}}\right)+H \frac{C_{\mathrm{c}}}{1+e_{0}} \log \left(\frac{\sigma_{0}+\Delta \sigma}{\sigma_{\mathrm{p}}}\right)$
19. $\delta=H \frac{C_{\alpha}}{1+e_{0}} \log \left(\frac{t}{t_{0}}\right)$

\section{Comparison of a new empirical approach with Moorhead (2013)}

To the authors' knowledge, there are no field studies explicitly isolating creep settlements with which to test the applicability of Equation 15. However, Equation 15 is considered in Figure 23 in the context of the laboratory measurements reported by Moorhead (2013). Moorhead's (2013) testing programme involved the use of stone columns to treat two different types of soil, considered to have insignificant (kaolin) and significant (Belfast soft silt, known as 'sleech') creep potential, respectively. Both rigid raft and isolated foundation scenarios were considered. For the isolated foundation loading scenario modelled, the initial conditions for the 'sleech' layer were different for the untreated and treated cases (for the reinforced case, the undrained shear strength of the clay bed was 20\% larger), leading to over-predicted settlement improvement factors. Accordingly, these data are not included in Figure 23.

Although the laboratory results clearly exhibit significant scatter, nine of the 12 datapoints in Figure 23 for the raft loading scenario (overconsolidated condition, 'OC') are in good agreement with Equation 15. This provides some confidence in the applicability of Equation 15 to soft soils, although further validation is required, ideally from full-scale research trials or stone columns in service.

\section{Conclusions}

Axisymmetric FE analysis techniques have been used to study the impact of creep on the behaviour of stone columns in soft cohesive soil deposits.

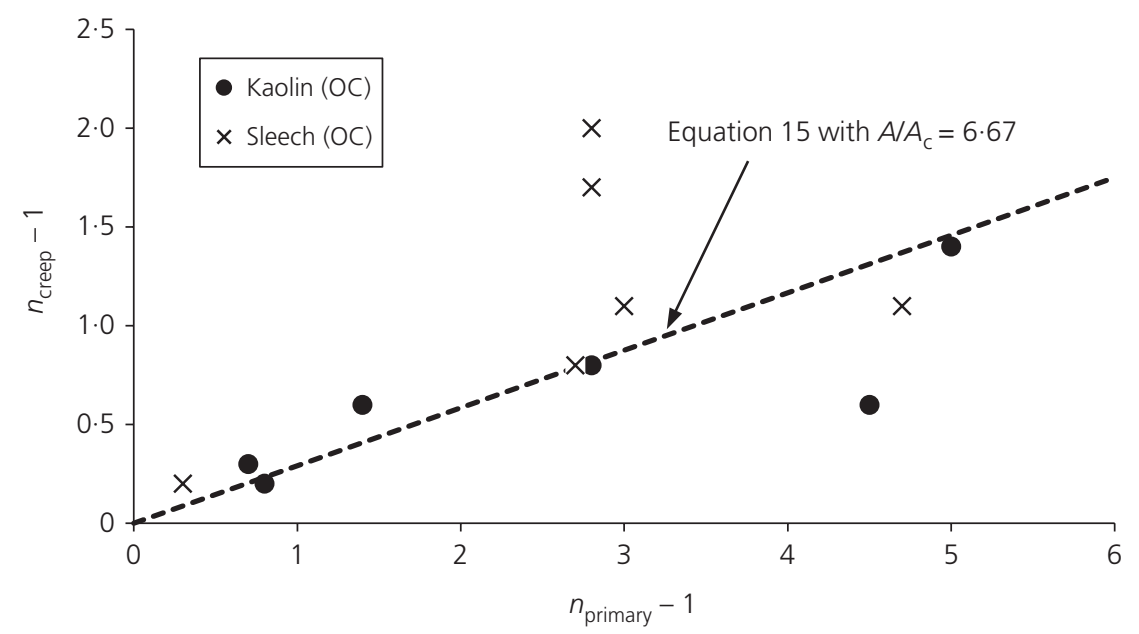

Figure 23. Comparison of Equation 15 with data from Moorhead (2013) 
The FE analyses have indicated that $n$ values in creep-prone soils will be over-predicted unless creep is accounted for in design. In addition, the findings have highlighted that the Madhav et al. $(2009,2010)$ formulation, which is based on elastic theory, will lead to over-predicted $n$ values in soft soils. The Madhav et al. $(2009,2010)$ formulation also predicts a soil overconsolidation effect due to the stress transfer process from soil to column while the soil creeps (additional to Bjerrum's (1967) ageing effect). However, the FE analyses in this paper (which account for plasticity) suggest that this soil overconsolidation effect will not benefit the combined soil-column system because the surplus load transferred to the stone column, which has already reached its active state/yield point, induces additional yielding.

The influence of a practical range of soil parameters on $n_{\text {primary, }}$, $n_{\text {total }}$ and $n_{\text {creep }}$ has been studied to assess the applicability of the findings to a spectrum of soft clays. The influence of the different parameters on the average vertical effective stresses in the soil and column for $A / A_{\mathrm{c}}=3,6$ and 10 has also been studied. The outcomes may be summarised as follows

- Regardless of the parameters adopted, the presence of creep gives rise to lower $n$ values than if only primary consolidation was considered.

- The magnitude of vertical stress transferred from soil to column due to creep is more pronounced in soils with higher $\mu^{*}$ values because additional yielding is induced in the columns.

- The amount of stress transferred from soil to column due to creep is largely independent of $\lambda^{*}, \kappa^{*}$ and $\phi_{\mathrm{s}}^{\prime}$.

- The stress transfer due to creep is more significant at the lower load level considered in this study because full yielding of the granular material is not induced for the 'without creep' case and so there is more scope for stress transfer from soil to column due to creep.

The FE output has been used to develop a simple empirical approach to incorporate potential improvement to creep settlements into the vibro-replacement design process. The approach is applicable to end-bearing columns, with spacings in the range $3<A / A_{\mathrm{c}}<10$ for which the influence of modular ratio is small, and can be used in tandem with any pre-existing primary settlement design method.

\section{Acknowledgement}

The authors acknowledge the Irish Research Council (IRC) for providing an 'Embark Initiative' scholarship to fund this research.

\section{REFERENCES}

Allman MA and Atkinson JH (1992) Mechanical properties of reconstituted Bothkennar soil. Géotechnique 42(2): 289-301, https://doi.org/10.1680/geot.1992.42.2.289.
Ambily AP and Gandhi SR (2007) Behavior of stone columns based on experimental and FEM analysis. Journal of Geotechnical and Geoenvironmental Engineering 133(4): 405-415.

Azzouz AS, Baligh MM and Whittle AJ (1990) Shaft resistance of piles in clay. Journal of Geotechnical Engineering 116(2): 205-221.

Balaam NP and Booker JR (1981) Analysis of rigid rafts supported by granular piles. International Journal for Numerical and Analytical Methods in Geomechanics 5(4): 379-403.

Barksdale RD and Bachus RC (1983) Design and Construction of Stone Columns - Volume I. Federal Highway Administration Report FHWA/RD-83/026, National Technical Information Service, Springfield, VA, USA.

Bjerrum L (1967) Engineering geology of Norwegian normally-consolidated marine clays as related to settlements of buildings. Seventh Rankine Lecture. Géotechnique 17(2): 81-118, https://doi.org/10.1680/geot.1967.17.2.83.

Black JA, Sivakumar V and Bell A (2011) The settlement performance of stone column foundations. Géotechnique 61(11): 909-922, https://doi.org/10.1680/geot.9.P.014.

Bodas Freitas TM (2008) Numerical Modelling of the Time Dependent Behaviour of Clays. Master's thesis, Imperial College London, London, UK.

Brinkgreve RBJ, Swolfs WM and Engin E (2011) PLAXIS 2D 2010. Plaxis B.V., Delft, the Netherlands.

Casagrande A (1936) The determination of the pre-consolidation load and its practical significance. Proceedings of the 1 st International Conference on Soil Mechanics and Foundation Engineering, Cambridge, MA, USA. ASCE, Reston, VA, USA, vol. 3 , pp. $60-64$.

Castro J and Sagaseta C (2009) Consolidation around stone columns. Influence of column deformation. International Journal for Numerical and Analytical Methods in Geomechanics 33(7): $851-877$.

Degago SA (2011) On Creep during Primary Consolidation of Clays. PhD thesis, Norwegian University of Science and Technology (NTNU), Trondheim, Norway.

Degago SA, Grimstad G, Jostad HP, Nordal S and Olsson M (2011) Use and misuse of the isotache concept with respect to creep hypotheses A and B. Géotechnique 61(10): 897-908, https://doi.org/10.1680/geot.9.P.112.

Ellouze S and Bouassida M (2009) Prediction of the settlement of reinforced soft clay by a group of stone columns. Proceedings of the 2nd International Conference on New Developments in Soil Mechanics and Geotechnical Engineering, Nicosia, North Cyprus. International Society of Soil Mechanics \& Geotechnical Engineering, London, UK, pp. 182-187.

Fatahi B, Le TM and Khabbaz H (2012) Influence of soil creep on stability of embankment on soft soil. Proceedings of the International Conference on Ground Improvement and Ground Control (ICGI 2012), Wollongong, Australia. Research Publishing, Singapore, Singapore, vol. 1, pp. 485-490.

Gäb M, Schweiger HF, Kamrat-Pietraszewska D and Karstunen M (2008) Numerical analysis of a floating stone column foundation using different constitutive models. Proceedings of the 2 nd International Workshop on the Geotechnics of Soft Soils - Focus on Ground Improvement, Glasgow, UK. Taylor \& Francis, Abingdon, UK, pp. 137-142.

Hight DW, Bond AJ and Legge JD (1992) Characterization of the Bothkennar clay: an overview. Géotechnique 42(2): 303-347, https://doi.org/10.1680/geot.1992.42.2.303.

ICE (Institution of Civil Engineers) (1992) Bothkennar soft clay test site: characterization and lessons learned. Géotechnique 42(2): 161-378. 
Jardine RJ, Lehane BM, Smith PR and Gildea PA (1995) Vertical loading experiments on rigid pad foundations at Bothkennar. Géotechnique 45(4): 573-597, https://doi.org/10.1680/ geot.1995.45.4.573.

Killeen MM and McCabe BA (2014) Settlement performance of pad footings on soft clay supported by stone columns: a numerical study. Soils and Foundations 54(4): 760-776.

Kok Shien NG (2013) Numerical Study of Floating Stone Columns. $\mathrm{PhD}$ thesis, National University of Singapore, Singapore, Singapore.

Lee JS and Pande GN (1998) Analysis of stone-column reinforced foundations. International Journal for Numerical and Analytical Methods in Geomechanics 22(12): 1001-1020.

Lo KY and Hinchberger SD (2006) Stability analysis accounting for macroscopic and microscopic structures in clays. Proceedings of the 4th International Conference on Soft Soil Engineering, Vancouver, Canada. CRC Press, Boca Raton, FL, USA, pp. 3-34.

Lopes PJG (2011) Colunas de Brita no Melhoramento de Solos Moles. Universidade de Aveiro, Aveiro, Portugal (in Portuguese).

Madhav MR, Suresh K and Nirmala Peter EC (2009) Creep effect on response of granular pile reinforced ground. Ground Improvement Technologies and Case Histories, Singapore. Research Publishing, Singapore, Singapore, pp. 275-284.

Madhav MR, Suresh K and Peter ECN (2010) Effect of creep on settlement of granular pile reinforced ground. International Journal of Geotechnical Engineering 4(4): 495-505.

McCabe BA, Nimmons GJ and Egan D (2009) A review of field performance of stone columns in soft soils. Proceedings of the Institution of Civil Engineers - Geotechnical Engineering 162(6): 323-334, https://doi.org/10.1680/geng.2009.162.6.323.

Mesri G and Godlewski PM (1977) Time and stress-compressibility interrelationship. Journal of the Geotechnical Engineering Division 103(5): 417-430.

Mitchell JK and Huber TR (1985) Performance of a stone column foundation. Journal of Geotechnical Engineering 111(2): 205-223.

Mitchell JK and Kelly R (2013) Addressing some current challenges in ground improvement. Proceedings of the Institution of Civil Engineers - Ground Improvement 166(3): 127-137, https://doi.org/10.1680/grim.12.00030.

Moorhead MC (2013) Effectiveness of Granular Columns for Containing Settlement of Foundations Supported on Soft Clay. PhD thesis, The Queen's University, Belfast, UK.

Nash DFT (2001) Modelling the effects of surcharge to reduce long term settlement of reclamations over soft clays: a numerical case study. Soils and Foundations 41(5): 1-13.

Nash DFT and Ryde SJ (2001) Modelling consolidation accelerated by vertical drains in soils subject to creep. Géotechnique 51(3): 257-273, https://doi.org/10.1680/geot.2001.51.3.257.

Nash DFT, Sills GC and Davison LR (1992) One-dimensional consolidation testing of soft clay from Bothkennar. Géotechnique 42(2): 241-256, https://doi.org/10.1680/geot.1992.42.2.241.

Neher HP, Sterr C, Messerklinger S and Koskinen M (2003) Numerical modelling of anisotropy of Otaniemi Clay. Proceedings of the International Workshop 'Geotechnics of Soft Soils. Theory and Practice', Noordwijkerhout, The Netherlands. Verlag Gluckauf $\mathrm{GmbH}$, Essen, Germany, pp. 21-230.

Priebe HJ (1995) The design of vibro replacement. Ground Engineering 28(10): 31-37.

Pugh R (2016) Settlement of floor slabs on stone columns in very soft clays. Proceedings of the Institution of Civil Engineers - Geotechnical Engineering 170(1): 16-26, http:/l dx.doi.org/10.1680/jgeen.15.00150.

Pulko B, Majes B and Logar J (2011) Geosynthetic-encased stone columns: analytical calculation model. Geotextiles and Geomembranes 29(1): 29-39.
Schanz T, Vermeer PA and Bonnier PG (1999) The hardening soil model: formulation and verification. Beyond 2000 in Computational Geotechnics - Ten Years of PLAXIS International, Amsterdam, the Netherlands. Balkema, Rotterdam, the Netherlands, pp. 281-290.

Schweiger HF and Pande GN (1986) Numerical analysis of stone column supported foundations. Computers and Geotechnics 2(6): $347-372$.

Sexton BG (2014) The Influence of Creep on the Settlement of Foundations Supported by Stone Columns. PhD thesis, National University of Ireland, Galway, Ireland.

Sexton BG and McCabe BA (2012) A preliminary numerical study of the improvement to secondary settlement offered by granular columns. Proceedings of the International Conference on Ground Improvement and Ground Control (ICGI 2012), Wollongong, Australia. Research Publishing, Singapore, Singapore, vol. 1, pp. 685-690.

Sexton BG and McCabe BA (2013) Numerical modelling of the improvements to primary and creep settlements offered by granular columns. Acta Geotechnica 8(4): 447-464.

Sexton BG and McCabe BA (2015) Modelling stone column installation in an elasto-viscoplastic soil. International Journal of Geotechnical Engineering 9(5): 500-512.

Sexton BG and McCabe BA (2016) Stone column effectiveness in soils with creep: a numerical study. Geomechanics and Geoengineering 11(4): 252-269.

Sexton BG, McCabe BA and Castro J (2014) Appraising stone column settlement prediction methods using finite element analyses. Acta Geotechnica 9(6): 993-1011.

Sexton BG, McCabe BA, Karstunen M and Sivasithamparam N (2016) Stone column settlement performance in structured anisotropic clays: the influence of creep. Journal of Rock Mechanics and Geotechnical Engineering 8(5): 672-688.

Shahu JT, Madhav MR and Hayashi S (2000) Analysis of soft ground-granular pile-granular mat system. Computers and Geotechnics 27(1): 45-62.

Simons NE and Som NN (1970) Settlement of Structures on Clay: With Particular Emphasis on London Clay. Ciria (Construction Industry Research and Information Association), London, UK, Report 22.

Suhonen K (2010) Creep of Soft Clay. Master's thesis, Aalto University, Helsinki, Finland.

Šuklje L (1957) The analysis of the consolidation process by the isotaches method. Proceedings of the 4th International Conference on Soil Mechanics and Foundation Engineering, London, UK. Butterworths, London, UK, vol. 1, pp. 200-206.

Van Impe WF and De Beer E (1983) Improvement of settlement behaviour of soft layers by means of stone columns. Proceedings of the 8th European Conference on Soil Mechanics and Foundation Engineering, Helsinki, Finland. Balkema, Rotterdam, the Netherlands, vol. 1, pp. 309-312.

Vermeer PA and Neher HP (1999) A soft soil model that accounts for creep. Beyond 2000 in Computational Geotechnics. Ten Years of PLAXIS International, Amsterdam, the Netherlands. Balkema, Rotterdam, the Netherlands, pp. 249-261.

Vermeer PA, Stolle DFE and Bonnier PG (1998) From the classical theory of secondary compression to modern creep analysis. Proceedings of the 9th International Conference on Computer Methods and Advances in Geomechanics, Wuhan, China. Balkema, Rotterdam, the Netherlands, vol. 4, pp. 2469-2478.

Watts KS, Johnson D, Wood LA and Saadi A (2000) An instrumented trial of vibro ground treatment supporting strip foundations in a variable fill. Géotechnique 50(6): 699-708, https://doi.org/10.1680/ geot.2000.50.6.699. 
Yin JH and Graham J (1989) Viscous-elastic-plastic modelling of one-dimensional time-dependent behaviour. Canadian Geotechnical Journal 26(2): 199-209.

Yin JH and Graham J (1994) Equivalent times and one-dimensional elastic visco-plastic modelling of time-dependent stress-strain behaviour of clays. Canadian Geotechnical Journal 31(1): 42-52.
Yin JH and Graham J (1996) Elastic visco-plastic modelling of one-dimensional consolidation. Géotechnique 46(3): 515-527, https://doi.org/10.1680/geot.1996.46.3.515.

Yin ZY and Karstunen M (2011) Modelling strain-rate-dependency of natural soft clays combined with anisotropy and destructuration. Acta Mechanica Solida Sinica 24(3): 216-230.

\section{How can you contribute?}

To discuss this paper, please email up to 500 words to the editor at journals@ice.org.uk. Your contribution will be forwarded to the author(s) for a reply and, if considered appropriate by the editorial board, it will be published as discussion in a future issue of the journal.

Proceedings journals rely entirely on contributions from the civil engineering profession (and allied disciplines). Information about how to submit your paper online is available at www.icevirtuallibrary.com/page/authors, where you will also find detailed author guidelines. 